\title{
Targeting metabotropic glutamate receptors for novel treatments of schizophrenia
}

\author{
James Maksymetz ${ }^{1,2}$, Sean P. Moran ${ }^{2,3}$ and P. Jeffrey Conn ${ }^{1,2,3^{*}}$
}

\begin{abstract}
Support for the N-methyl-D-aspartate receptor (NMDAR) hypofunction hypothesis of schizophrenia has led to increasing focus on restoring proper glutamatergic signaling as an approach for treatment of this devastating disease. The ability of metabotropic glutamate $(\mathrm{mGlu})$ receptors to modulate glutamatergic neurotransmission has thus attracted considerable attention for the development of novel antipsychotics. Consisting of eight subtypes classified into three groups based on sequence homology, signal transduction, and pharmacology, the $\mathrm{mGlu}$ receptors provide a wide range of targets to modulate NMDAR function as well as glutamate release. Recently, allosteric modulators of mGlu receptors have been developed that allow unprecedented selectivity among subtypes, not just groups, facilitating the investigation of the effects of subtype-specific modulation. In preclinical animal models, positive allosteric modulators (PAMs) of the group I mGlu receptor $\mathrm{mGlu}_{5}$ have efficacy across all three symptom domains of schizophrenia (positive, negative, and cognitive). The discovery and development of $\mathrm{mGlu}_{5}$ PAMs that display unique signal bias suggests that efficacy can be retained while avoiding the neurotoxic effects of earlier compounds. Interestingly, mGlu negative allosteric modulators (NAMs) appear efficacious in positive symptom models of the disease but are still in early preclinical development. While selective group II mGlu receptor $\left(\mathrm{mGlu}_{2 / 3}\right)$ agonists have reached clinical trials but were unsuccessful, specific $\mathrm{mGlu}_{2}$ or $\mathrm{mGlu}_{3}$ receptor targeting still hold great promise. Genetic studies implicated $\mathrm{mGlu}_{2}$ in the antipsychotic effects of group $\|$ agonists and $\mathrm{mGlu}_{2}$ PAMs have since entered into clinical trials. Additionally, $\mathrm{mGlu}_{3}$ appears to play an important role in cognition, may confer neuroprotective effects, and thus is a promising target to alleviate cognitive deficits in schizophrenia. Although group III $\mathrm{mGlu}$ receptors $\left(\mathrm{mGlu}_{4 / 6 / 7 / 8}\right)$ have attracted less attention, $\mathrm{mGlu}_{4}$ agonists and PAMs appear to have efficacy across all three symptoms domains in preclinical models. The recent discovery of heterodimers comprising $\mathrm{mGlu}_{2}$ and $\mathrm{mGlu}_{4}$ may explain the efficacy of $\mathrm{mGlu}_{4}$ selective compounds but this remains to be determined. Taken together, compounds targeting mGlu receptors, specifically subtype-selective allosteric modulators, provide a compelling alternative approach to fill the unmet clinical needs for patients with schizophrenia.
\end{abstract}

Keywords: mGlu receptor, Schizophrenia, Allosteric modulator, Signal bias, Heterodimer, PAM, NAM, Glutamate

\footnotetext{
* Correspondence: jeff.conn@vanderbilt.edu

'Department of Pharmacology, Vanderbilt University, Nashville, TN 37232,

USA

²Vanderbilt Center for Neuroscience Drug Discovery, Nashville, TN 37232,

USA

Full list of author information is available at the end of the article
} 


\section{Introduction}

Schizophrenia is a devastating psychiatric disorder that afflicts approximately $1 \%$ of the worldwide population, affects women and men equally, and spans all socioeconomic groups [1]. The disease is characterized by three major symptom domains: positive, negative, and cognitive symptoms [2]. Current antipsychotics are effective at treating the positive symptoms such as auditory and visual hallucinations, delusions, and disorganized thoughts; however, they do not address the negative nor the cognitive symptoms. Negative symptoms (e.g., flattened affect, social withdrawal) and cognitive symptoms (e.g., deficits in working memory, and cognitive flexibility) are believed to be the best predictors of long-term outcome and are estimated to cost the U.S. healthcare system over $\$ 60$ billion per year [3-5]. Additionally, most patients discontinue current treatments due to adverse effects including extrapyramidal side effects (EPS) (i.e., dystonia, akathisia, parkinsonism, bradykinesia, tremor, and tardive dyskinesia) induced by first-generation typical antipsychotics and metabolic side effects (i.e., weight gain, type II diabetes, and hyperlipidosis) induced by second generation atypical antipsychotics [6-8].

While most current antipsychotics act by antagonizing the hyperdopaminergic and hyperserotonergic states underlying the positive symptoms, there is a growing body of evidence that supports glutamate dysfunction as a contributing factor for the disease $[9,10]$. For example, administration of the $\mathrm{N}$-methyl-D-aspartate receptor (NMDAR) antagonist phencyclidine (PCP) [11] induces a schizophrenia-like state that presents clinically with all three symptom clusters in healthy individuals [12, 13]. Similar clinical results have been found with administration of other NMDAR antagonists such as ketamine [14]. NMDAR antagonists also exacerbate or precipitate controlled symptoms when administered to schizophrenia patients [15]. This along with extensive preclinical evidence suggests that NMDAR hypofunction is important in the pathophysiology underlying schizophrenia [10].

Based on the NMDAR hypofunction hypothesis of schizophrenia, pharmacological agents that enhance NMDAR function are not only valuable tools in preclinical animal models but could also provide therapeutic benefits to patients with schizophrenia. Unfortunately, direct activation of NMDARs using traditional orthosteric agonists induces adverse effects such as excitotoxicity and seizures [16-20]. Furthermore, treatments with NMDAR obligate co-agonists such as glycine or serine failed to have consistent efficacy across multiple clinical trials [21]. More recently, selective NMDAR positive allosteric modulators (PAMs) that enhance receptor function in the presence of the endogenous agonists but are devoid of intrinsic activity have been reported [20]. It is possible that NMDAR PAMs could avoid the adverse effects associated with direct activation of NMDARs. The recent development of NMDAR PAMs such as GNE-6901 and GNE-8324 provide proof-ofprinciple for the development of allosteric modulators of NMDARs, however their poor pharmacokinetic properties and low central nervous system exposures hinder their uses for in vivo studies [20]. Therefore, it will be important to develop more optimized compounds to fully assess the ability of NMDAR PAMs to reverse schizophrenia-like symptoms in animal models without the adverse effects profile of NMDAR agonists.

In addition to NMDARs and other ionotropic glutamate receptors ( $\alpha$-amino-3-hydroxy-5-methyl-4-isoxazolepropionic acid (AMPA) and kainate receptors) that mediate fast excitatory neurotransmission, glutamate also binds to and signals through a family of G-protein coupled metabotropic glutamate (mGlu) receptors [22]. There are eight subtypes of mGlu receptors, $\mathrm{mGlu}_{1-8}$, classified into three groups (group I, $\mathrm{mGlu}_{1,5}$; group II, $\mathrm{mGlu}_{2,3}$; group III, $\left.\mathrm{mGlu}_{4,6,7,8}\right)$. mGlu receptors are class C GPCRs which function primarily as dimers and modulate glutamatergic, GABAergic, and neuromodulatory neurotransmission throughout the central nervous system (CNS) [22]. All three groups of mGlu receptors have been pursued as putative targets for novel antipsychotics due to their ability to directly alter NMDAR function or other aspects of glutamatergic signaling.

The highly conserved orthosteric glutamate binding site among mGlu receptor subtypes has generally precluded the design of subtype-specific receptor agonists or antagonists. This problem has been addressed by designing small molecule modulators that bind to distinct and subtype-unique allosteric sites within the 7 transmembrane domains of mGlu receptors allowing unprecedented selectivity against other glutamate receptors [23]. Positive allosteric modulators (PAMs) generally do not activate the receptor directly but instead potentiate responses to endogenous glutamate. Conversely, negative allosteric modulators (NAMs) act as non-competitive antagonists and may also have inverse agonist activity, reducing constitutive activity of the receptor in the absence of glutamate [24, 25].

\section{Group I mGlu receptors ( $\left.m \mathrm{Glu}_{1} \& \mathrm{mGlu}_{5}\right)$}

Group I mGlu receptors include $\operatorname{mGlu}_{1}[26,27]$ and $\mathrm{mGlu}_{5}$ [28], and are primarily coupled to the $G \alpha_{\mathrm{q}}$ subunit of the heterotrimeric G-protein. Canonical $G \alpha_{\mathrm{q}}$ signaling activates phospholipase $\mathrm{C}$ beta and causes downstream activation of protein kinase $C(P K C)$ via the generation of the second messengers diacylglycerol (DAG) and inositol triphosphate $\left(\mathrm{IP}_{3}\right)$. The group I mGlu receptors have emerged as attractive targets, initially based on their close coupling to the NMDAR via intracellular signaling pathways and scaffolding proteins including Homer, SHANK, and GKAP-PSD95 
[29-31] and their ability to potentiate NMDA responses in acute brain slices [32]. $\mathrm{mGlu}_{1}$ and $\mathrm{mGlu}_{5}$ are predominantly postsynaptic receptors, but they have also been identified on presynaptic terminals of GABAergic and glutamatergic neurons (Fig. 1) [33]. Group I mGlu receptors are found primarily as homodimers via interactions at the large extracellular N-terminal Venus flytrap domain of each monomer [34]. Emerging evidence points to group I mGlu receptors existing in a monomeric form with distinct neurodevelopmental patterns which may impact their pharmacological profiles at specific ages in rodents [35]. While the potential role of dimeric versus monomeric expression may have interesting implications for schizophrenia, further studies are required to investigate this phenomenon.

\section{mGlu $_{1}$}

Two recent independent studies have identified 12 rare deleterious nonsynonymous single nucleotide polymorphisms in the GRM1 gene encoding for mGlu $_{1}$ in

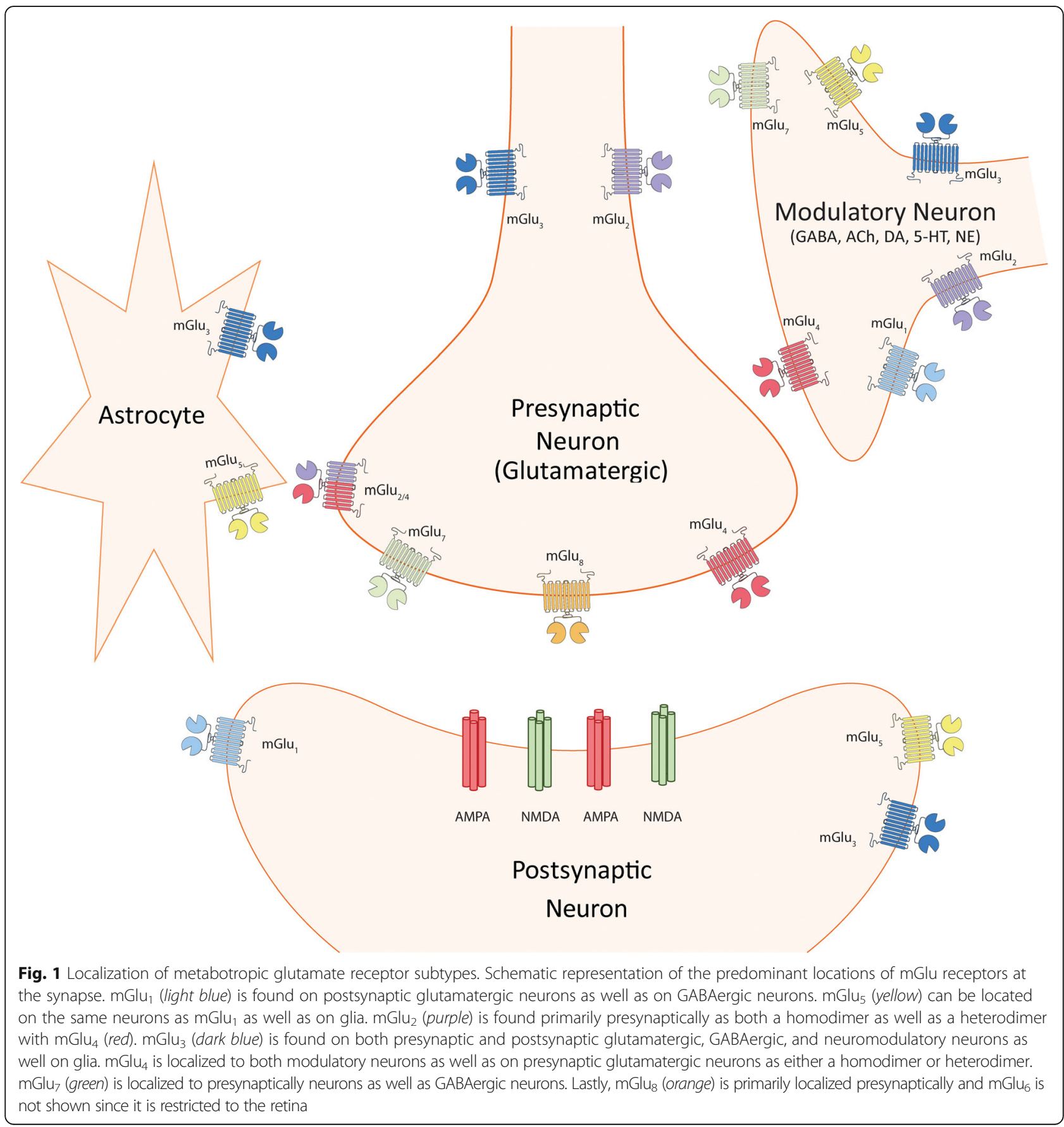


schizophrenia [36, 37]. Further support for $\mathrm{mGlu}_{1}$ dysregulation in schizophrenia is evidenced by postmortem findings in which mGlu ${ }_{1}$ mRNA expression is altered compared to controls [38]. Preclinically, Grm1 knockout mice display deficits in prepulse inhibition (PPI) [39], a behavioral assessment of sensory gating which is the process of filtering unnecessary stimuli from total sensory stimuli and which is impaired in schizophrenia patients [40]. Interestingly, recent studies reveal that GRM1 mutations associated with schizophrenia reduce $\mathrm{mGlu}_{1}$ signaling in cell lines and that selective $\mathrm{mGlu}_{1}$ PAMs can partially rescue the reduction in glutamate-mediated calcium signaling in vitro [41]. Therefore, enhancing $\mathrm{mGlu}_{1}$ signaling through selective agents has the potential to rescue deficits in schizophrenia patients with deleterious GRM1 mutations.

In addition to rescuing $\mathrm{mGlu}_{1}$ signaling deficits, activators or positive modulators of $\mathrm{mGlu}_{1}$ may also act to counteract the hyperdopaminergic signaling in the striatum in schizophrenia patients [42-45]. Multiple studies have demonstrated that the pan-mGlu receptor agonist trans-ACPD is able to attenuate stimulationinduced dopamine release in the dorsal striatum [46], the substantia nigra [47], and the nucleus accumbens [48]. In a follow up study, mGlu ${ }_{1}$ was identified as the subtype responsible for this effect in the dorsal striatum

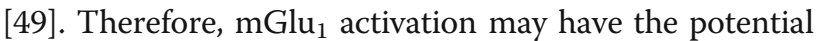
to produce similar antipsychotic effects as $\mathrm{D}_{2}$ dopamine receptor antagonist antipsychotics.

Potent first generation mGlu 1 PAMs were developed in the early 2000s, but poor drug metabolism and pharmacokinetic (DMPK) profiles limited their use in preclinical studies [50, 51]. More recent efforts yielded VU6000799 and VU6000790 as potent, highly selective $\mathrm{mGlu}_{1}$ PAMs with improved DMPK properties and brain penetrance, and are therefore better suited for in vivo studies [52-55]. In the future, it will be important to evaluate these compounds in animal models that are relevant to the three symptom domains of schizophrenia.

Important to the potential utility of $\mathrm{mGlu}_{1}$ PAMs to treat schizophrenia, it has been reported that the mGlu ${ }_{1}$ NAMs FTIDC and CFMTI are efficacious in animal models predictive of antipsychotic activity (Table 1), including reducing psychostimulant and NMDAR antagonist-induced hyperlocomotion and deficits in PPI as well as reversing deficits in social interaction induced by the NMDAR antagonist MK-801 in rats [56-58]. The contrasting findings of mGlu $_{1}$ PAMs, NAMs, and GRM1 knockout animals illustrate the potential complexity of $\mathrm{mGlu}_{1}$ ligands, and suggests that $\mathrm{mGlu}_{1}$ PAMs may only be effective in patients

Table 1 Summary of Preclinical Efficacy of Group I mGlu Receptor Ligands

\begin{tabular}{|c|c|c|c|}
\hline & Positive Symptom Models & Negative Symptom Models & Cognition Models \\
\hline \multicolumn{4}{|l|}{ mGlu, PAMs } \\
\hline VU0483605 & No effect on AHL [41] & & \\
\hline \multicolumn{4}{|l|}{ mGlu, NAMs } \\
\hline FTIDC & $\begin{array}{l}\text { Reduced methamphetamine } \\
\text { hyperlocomotion (MHL) [56] } \\
\text { Ameliorated METH-induced } \\
\text { deficits in PPI [56] }\end{array}$ & & \\
\hline CFMTI & $\begin{array}{l}\text { Reduced MHL and NMDAR } \\
\text { antagonist-induced } \\
\text { hyperlocomotion } \\
\text { (NMDAR-HL) [57] } \\
\text { Ameliorated METH and } \\
\text { KET-disrupted PPI [57] }\end{array}$ & $\begin{array}{l}\text { Ameliorated MK-801-disrupted social } \\
\text { interaction [57] }\end{array}$ & $\begin{array}{l}\text { No effect on object location memory } \\
\text { (OLM) [57] }\end{array}$ \\
\hline \multicolumn{4}{|l|}{$\mathrm{mGlu}_{5}$ PAMs } \\
\hline CDPPB & $\begin{array}{l}\text { Reduced AHL [70] } \\
\text { Ameliorated AMP-disrupted } \\
\text { PPI }[69,70]\end{array}$ & $\begin{array}{l}\text { Attenuated MK-801-induced decrease } \\
\text { in sucrose preference [223] }\end{array}$ & $\begin{array}{l}\text { Enhanced learning in Morris water } \\
\text { maze (MWM) [72] } \\
\text { Attenuated MK-801-induced deficits } \\
\text { in cognitive flexibility [224] } \\
\text { Improved PCP-induced deficits in } \\
\text { novel object recognition (NOR) [225] }\end{array}$ \\
\hline 5PAM523 & Reduced AHL [76] & & \\
\hline VU0409551 & $\begin{array}{l}\text { Reduced AHL and } \\
\text { NMDAR-HL [81] }\end{array}$ & & $\begin{array}{l}\text { Enhanced contextual fear conditioning } \\
\text { (CF) [81] } \\
\text { Enhanced NOR [81] } \\
\text { Enhanced working memory/executive } \\
\text { function in the delayed non-matching } \\
\text { to position (DNMTP) task [81] } \\
\text { Improved contextual CF deficits in } \\
\mathrm{SR}^{-/-} \text {mice [81] }\end{array}$ \\
\hline
\end{tabular}


carrying GRM1 mutations. These studies further highlight the heterogeneity of schizophrenia and the critical role of patient selection strategies in psychiatric clinical trials to match genotype with the therapy.

$\mathrm{mGlu}_{5}$

In recent years, $\mathrm{mGlu}_{5}$ has emerged as an attractive target for the treatment of schizophrenia [59]. Similar to $\mathrm{mGlu}_{1}, \mathrm{mGlu}_{5}$ is primarily postsynaptic but is also located presynaptically and can be expressed on GABAergic neurons and glia (Fig. 1). In the hippocampus, prefrontal cortex (PFC), and other brain regions, $\mathrm{mGlu}_{5}$ plays important roles in synaptic plasticity - the strengthening or weakening of synapses in response to specific activity patterns termed long term potentiation (LTP) and long term depression (LTD), respectively [60, 61]. Early pharmacological and genetic deletion studies in mice have shown that $\mathrm{mGlu}_{5}$ is important in the regulation of specific domains of cognitive function $[60,61]$ and in behaviors relevant for the positive and negative symptoms of schizophrenia [39, 62, 63]. Interestingly, unlike $\mathrm{mGlu}_{1}$, early studies did not provide evidence that $\mathrm{mGlu}_{5}$ activation reduces dopamine release in the striatum $[64,65]$ thus any antipsychotic effects of $\mathrm{mGlu}_{5}$ activators may be independent of dopamine modulation.

Over the last two decades, a growing body of evidence

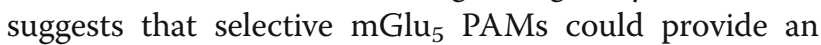
exciting new approach for the treatment of schizophrenia [66] (Table 1). The first highly selective $\mathrm{mGlu}_{5}$ PAMs DFB [67] and CPPHA [68] demonstrated the viability of developing selective compounds for $\mathrm{mGlu}_{5}$, but lacked properties that would allow their use in vivo. The first major in vivo breakthrough came with the development of CDPPB [69], the first $\mathrm{mGlu}_{5}$ PAM to possess favorable DMPK properties to allow its use in rodent models $[69,70]$. Subsequently, it was shown that CDPPB reverses AHL and amphetamine-induced disruption of PPI in rats, providing strong preclinical support for $\mathrm{mGlu}_{5}$ as a potential therapeutic for schizophrenia [70]. In more recent years, there has been tremendous success in developing a large number of structurally distinct, highly selective mGlu ${ }_{5}$ PAMs that have efficacy in a wide range of animal models relevant to all three symptom domains of schizophrenia [71-76].

Since $\mathrm{mGlu}_{5}$ can potentiate NMDAR responses in select rodent brain regions [77-79], it was initially proposed that $\mathrm{mGlu}_{5}$ PAMs were likely to exert their efficacy through potentiation of $\mathrm{mGlu}_{5}$-induced increases in NMDAR currents in forebrain regions implicated in the pathology of schizophrenia [72, 79]. Unfortunately, some mGlu $_{5}$ PAMs, such as 5PAM523 which has efficacy in reversing AHL, appear to induce severe adverse effects including seizures and neuronal death which could be related to excessive activation of NMDAR $[76,80]$. Until recently, the hypothesis that potentiation of $\mathrm{mGlu}_{5}$ modulation of NMDAR currents was critical for the efficacy of these compounds had not been tested. To systematically test this, a novel biased mGlu $_{5}$ PAM, VU0409551, was developed that potentiates mGlu $_{5}$ coupling to $\mathrm{G \alpha}_{\mathrm{q}}$-mediated calcium mobilization and other canonical signaling pathways but does not enhance $\mathrm{mGlu}_{5}$ changes in NMDAR currents (Fig. 2a) [81]. Of interest, VU0409551 produces robust antipsychotic-like effects in pharmacological challenge models of positive psychotic symptoms and cognition-enhancing effects in wild-type animals [81]. VU0409551 also has robust efficacy in reversing deficits in serine racemase knockout $\left(\mathrm{SR}^{-1-}\right)$ mice, a genetic model of NMDAR hypofunction in which the enzyme that synthesizes the NMDAR coagonist $\mathrm{D}$-serine is genetically deleted [82]. $\mathrm{SR}^{-/-}$mice display deficits in synaptic plasticity and cognition [83], and recapitulate anhedonic-like symptoms, such as a blunted reward response to cocaine in an intracranial self-stimulation paradigm [84]. Interestingly, VU0409551 rescues signaling, plasticity, and cognitive deficits in this model [82], strengthening the hypothesis that biased mGlu $_{5}$ PAMs that do not potentiate NMDAR currents still retain efficacy in rodent models relevant for schizophrenia. Furthermore, chronic administration of VU0409551 at doses over $100 \times$ those required to achieve in vivo efficacy resulted in no measureable cell death or induction of seizures [81]. In addition, separate studies revealed that eliminating allosteric agonist activity of $\mathrm{mGlu}_{5}$ PAMs is critical for reducing seizure liability [80]. Thus, by developing a detailed understanding of the pharmacodynamic actions of different mGlu $_{5}$ PAMs, it may be possible to develop $\mathrm{mGlu}_{5}$ PAM clinical candidates that have robust efficacy but are devoid of excitotoxic adverse effects (Fig. 2a).

The mechanism by which VU0409551 exerts its antipsychotic-like and procognitive effects in animal models remains unclear. Experiments in wild-type rats suggest that the ability of VU0409551 to enhance certain forms of cognition is independent of NMDAR modulation [81]. It is possible that these effects of the PAM are due to the potentiation of $\mathrm{mGlu}_{5}$-mediated effects on neuronal excitability aside from NMDAR current modulation. In CA1 pyramidal cells $\mathrm{mGlu}_{5}$ activation suppresses the afterhyperpolarization current, thereby increasing the excitability of these neurons [79]. In these same neurons, mGlu $_{5}$ is critical for a form of long-term plasticity at inhibitory synapses, termed inhibitory long-term depression (iLTD), and an $\mathrm{mGlu}_{5}$ PAM could increase hippocampal transmission via a reduction of inhibitory tone [85]. In layer $\mathrm{V}$ pyramidal neurons in the rodent medial PFC, $\mathrm{mGlu}_{5}$ activation increases neuronal excitability and spiking frequency $[86,87]$ as well as excitatory drive onto these neurons [88]. One hypothesis is that VU0409551 exerts 


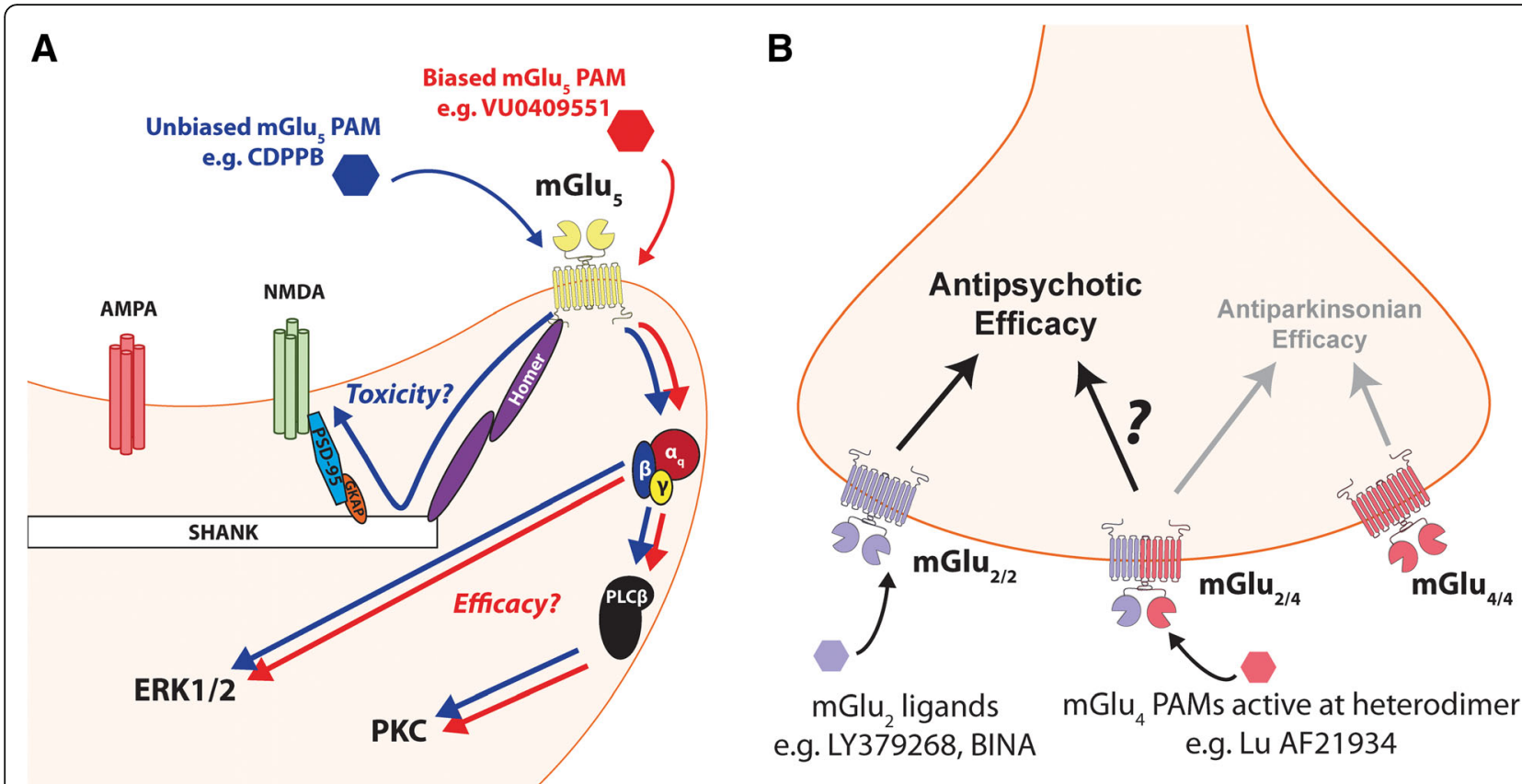

Fig. 2 Emerging concepts in the development of mGlu receptor-targeting antipsychotic therapeutics. a mGlu ${ }_{5}$ PAMs have recently been developed that bias $\mathrm{mGlu}_{5}$ signaling away from NMDAR modulation but still mobilize intracellular $\mathrm{Ca}^{2+}$ and activate ERK1/2. The mechanism of this bias is still unclear but could involve G-protein dependent versus independent coupling of mGlu ${ }_{5}$ to NMDAR. The biased mGlu ${ }_{5}$ PAM VU0409551 retains antipsychotic-like efficacy in vivo but does not cause excitotoxicity or seizures observed with unbiased mGlu ${ }_{5}$ PAMs that enhance mGlu ${ }_{5}$-mediated modulation of NMDAR currents. This suggests that NMDAR modulation is not necessary for in vivo efficacy and that this signal bias may provide a means to overcome the NMDAR-mediated excitotoxicity that has stalled mGlu, PAM development. b Recently, functional mGlu 2 / ${ }_{4}$ heterodimers with unique pharmacology have been identified. This suggests that actions at the $\mathrm{mGlu}_{2 / 4}$ heterodimer rather than at the $\mathrm{mGlu}_{4 / 4}$ homodimer might underlie the antipsychotic efficacy of mGlu 4 PAMs, such as Lu AF21934, consistent with the antipsychotic-like effects of $\mathrm{mGlu}_{2}$-specific ligands. This remains to be tested experimentally but may provide an interesting alternative to failed mGlu $\mathrm{clinical}$ programs

its procognitive effects, especially the augmentation of PFC-dependent recognition memory, working memory, and executive function [81], via increased PFC pyramidal neuron activity but this remains untested.

In vitro assays indicate that VU0409551 exerts both PAM and robust agonist activity with respect to $\mathrm{mGlu}_{5^{-}}$ mediated extracellular-signal regulated kinase (ERK) activity. This is in agreement with the ability of VU0409551 to enhance LTD at the Schaffer Collateral-CA1 (SC-CA1) synapse induced by the group I mGlu receptor agonist DHPG, a form of plasticity that involves rapid protein synthesis and ERK activation [89-91]. Additionally, augmentation of early-phase LTP (E-LTP; $<3 \mathrm{~h}$ ) by mGlu $_{5}$ PAMs may require NMDAR current potentiation, explaining why VU0409551 does not augment E-LTP. While E-LTP is not dependent on ERK activity nor protein synthesis, late-phase LTP $(>3 \mathrm{~h})$ is ERK-dependent [92], can be enhanced by $\mathrm{mGlu}_{5}$ PAMs [93] and is closely linked to long term memory consolidation. Therefore, VU0409551 via its positive effects on ERK activation may exert its procognitive effects by potentiating late-phase LTP, although this remains to be tested experimentally.
Interestingly, VU0409551 is able to rescue deficits in hippocampal E-LTP in $\mathrm{SR}^{-/}$mice without any augmentation in littermate controls [82]. This effect also correlates with the ability of VU0409551 to enhance NMDAR synaptic responses exclusively in the knockout mice. How VU0409551 exerts these effects in animals with marked NMDAR hypofunction [94] but not in wildtype animals remains to be determined. It is still unclear how prototypical $\mathrm{mGlu}_{5}$ PAMs enhance NMDAR function in wild-type animals $[68,81]$ as studies have implicated both G-proteindependent [95-98] and G-protein-independent [99102] pathways in the $\mathrm{mGlu}_{5}-\mathrm{NMDAR}$ interaction (Fig. 2a). Therefore, the actions of VU0409551 in SR $-{ }_{-}$mice could involve a rearrangement of the postsynaptic density to prefer G-protein-independent mGlu $_{5}$-mediated NMDAR current enhancement or differential spatial and/or temporal coupling of $\mathrm{mGlu}_{5}$ to G-protein-dependent downstream effectors that could augment NMDARs such as PKC and CaMKII. Future work is still needed to determine how $\mathrm{mGlu}_{5}$ PAMs enhance NMDAR function in wild-type animals and schizophrenia-like animal models. 


\section{Group II $\mathbf{m G l u}$ receptors $\left(\mathrm{mGlu}_{\mathbf{2}} \& \mathbf{m G l u}_{\mathbf{3}}\right.$ )}

The group II mGlu receptors, $\mathrm{mGlu}_{2}$ and $\mathrm{mGlu}_{3}$ [103], are expressed presynaptically [22] outside of the active zone on pre-terminal regions of axons where they can be activated by astrocytic glutamate release or excessive synaptic glutamate [104] (Fig. 1). $\mathrm{mGlu}_{3}$ is also found postsynaptically as well as on astrocytes where it mediates neuroprotective effects [104] and participates in astrocyticneuronal communication [105, 106] (Fig. 1). Group II mGlu receptors traditionally couple to the $\mathrm{G \alpha}_{\mathrm{i} / \mathrm{o}}$ subunits of G-proteins, leading to inhibition of adenylyl cyclase and other signaling pathways [22].

Due primarily to their inhibition of neurotransmitter release from glutamatergic, GABAergic, and neuromodulatory (dopaminergic, noradrenergic, etc.) presynaptic terminals (Fig. 1), the group II mGlu receptors have attracted considerable attention as potential targets for novel antipsychotics. $\mathrm{mGlu}_{2 / 3}$ activation has been shown to reduce extracellular dopamine efflux in the nucleus accumbens [48, 64], the substantia nigra [47], and recently afferent-driven dopamine release in the dorsal striatum [107]. Additionally, elevated post-mortem glutamatergic markers are observed in the cortex of schizophrenia patients [108], commonly attributed to NMDAR dysfunction on GABAergic interneurons leading to an overall net disinhibition $[10,109,110]$. Furthermore, in both humans and animal models, NMDAR antagonist psychotomimetics increase glutamatergic transmission in the prefrontal cortex and increase CNS glutamate levels $[10,111-114] . \mathrm{mGlu}_{2 / 3}$ activation can inhibit glutamate release, therefore providing rationale for the development of agonists or potentiators of $\mathrm{mGlu}_{2 / 3}$ to reduce the excessive glutamatergic tone in the brain of patients with schizophrenia [115].

Directly relevant to NMDAR hypofunction, postsynaptic mGlu $_{2 / 3}$ activation can also enhance NMDAR currents in CA1 hippocampal pyramidal cells via Src kinase [116] as well as in PFC pyramidal cells via PKC [117] and SNAREdependent mechanisms [118]. It is currently unclear whether this enhancement of NMDAR currents contributes to the antipsychotic efficacy of $\mathrm{mGlu}_{2 / 3}$ activators but it is interesting that compounds targeting these receptors could provide a two-pronged approach: normalizing both NMDAR function and excessive glutamate levels in schizophrenia.

Of further importance, a functional heteromeric complex between the $5-\mathrm{HT}_{2 \mathrm{~A}}$ serotonin receptor $\left(5-\mathrm{HT}_{2 \mathrm{~A}} \mathrm{R}\right)$ and $\mathrm{mGlu}_{2}$ has been postulated based on biochemical, behavioral, and pharmacological data [119-121]. 5- $\mathrm{HT}_{2 \mathrm{~A}} \mathrm{R}$ agonists such as psychedelic hallucinogens typically induce a psychotomimetic state in humans [122] similar to observations with NMDAR antagonists. Activation of $5-\mathrm{HT}_{2 \mathrm{~A}} \mathrm{R}$ enhances thalamocortical neurotransmission in rodents $[123,124]$ and this effect is antagonized by activation of group II mGlu receptors [125]. Orthosteric agonists of $\mathrm{mGlu}_{2 / 3}$ functionally antagonize $5-\mathrm{HT}_{2 \mathrm{~A}}$ receptor signaling [119], therefore activators of $\mathrm{mGlu}_{2}$ may possess antipsychotic properties similar to atypical antipsychotics that partially rely on $5-\mathrm{HT}_{2 \mathrm{~A}} \mathrm{R}$ antagonism for their efficacy. An issue this raises for clinical trials is that antagonism of $5-\mathrm{HT}_{2 \mathrm{~A}}$ with atypical antipsychotics has been shown to downregulate expression of GRM2 (the gene encoding $\mathrm{mGlu}_{2}$ ) in rodents and decrease positive epigenetic markers of GRM2 expression in both mice and humans [126]. Based on these data, it may be essential to stratify future patient populations based on prior use of atypical serotonergic antipsychotics to ensure adequate target engagement and therapeutic efficacy of mGlu ${ }_{2}$ ligands.

\section{mGlu $_{2 / 3}$ agonists}

Interest in targeting $\mathrm{mGlu}_{2 / 3}$ for the treatment of schizophrenia began with the initial findings that the selective group II mGlu receptor orthosteric agonists LY354740 and LY379268 can reverse the ability of NMDAR antagonists to induce hyperlocomotion, stereotypies, deficits in working memory, cortical glutamate efflux, and increased firing of PFC neurons in rats [114, 127, 128] (Table 2). One of the most intriguing results of these studies was that activation of group II mGlu receptors had no effect on the NMDAR antagonist-induced rise in extracellular dopamine in the CNS [127]. Despite this, group II mGlu receptor agonists still retained antipsychotic-like efficacy in a range of animal models, suggesting the possibility of treating psychosis without the extrapyramidal or other adverse effects associated with dopaminergic antipsychotics. On the other hand, when the $\mathrm{mGlu}_{2 / 3}$ agonist LY404039 was administered to rats, it caused an increase in extracellular dopamine, the dopamine metabolites 3,4-dihydroxyphenylacetic acid (DOPAC) and homovanillic (HVA), and the serotonin metabolite 5-hydroxyindoleacetic acid (5-HIAA) in the PFC $[129,130]$. In contrast to the hyperdopaminergic state in the striatum thought to underlie the positive symptoms of schizophrenia, it is hypothesized that the negative symptoms of the disease are contributed to by a dearth of dopamine and serotonin release in cortical regions [131-134]. Therefore, the increased dopamine as well as dopamine and serotonin turnover observed in the rat PFC in response to LY404039 [129] may predict efficacy in treating some aspects of the negative symptoms of schizophrenia.

Based on the extensive preclinical evidence in support of $\mathrm{mGlu}_{2 / 3}$ agonists as novel antipsychotics, Eli Lilly \& Co. progressed LY2140023 monohydrate (pomaglumetad methionil; prodrug of the active $\mathrm{mGlu}_{2 / 3}$ agonist LY404039) into clinical trials and demonstrated safety and tolerability in humans [135]. In a 4-week multicenter proof-of-concept phase II clinical trial of 196 patients 
Table 2 Summary of Preclinical Efficacy of Group II mGlu Receptor Ligands

\begin{tabular}{|c|c|c|c|}
\hline & Positive Symptom Models & Negative Symptom Models & Cognition Models \\
\hline \multicolumn{4}{|l|}{$m G / u_{2 / 3}$ agonists } \\
\hline LY354740 & $\begin{array}{l}\text { Reduced NMDAR-HL }[127,226] \\
\text { No effect on AHL }[226,227] \\
\text { Reduced NMDAR antagonist-induced } \\
\text { stereotypies [127, 128] } \\
\text { No effect on apomorphine-disrupted } \\
\text { PPI [227] } \\
\text { Inhibited DOl-induced head twitches [228] }\end{array}$ & $\begin{array}{l}\text { Reduced PCP-induced deficits in social } \\
\text { interaction [229] }\end{array}$ & $\begin{array}{l}\text { Reduced PCP-induced deficits in the } \\
\text { discrete-trial delayed alternation (DTDA) } \\
\text { task [127] } \\
\text { Impaired performance in delayed matching } \\
\text { to position (DMTP) and DNMTP tasks [143] }\end{array}$ \\
\hline LY379268 & $\begin{array}{l}\text { Reduced NMDAR-HL and AHL [141, 226, 230] } \\
\text { No effect on PCP- or AMP-disrupted } \\
\text { PPI [141] } \\
\text { Inhibited DOI-induced head twitches [228] } \\
\text { Reduced prenatal restraint-induced } \\
\text { HL/PPI deficits [231] } \\
\text { Reversed postnatal isolation-induced } \\
\text { HL/PPI deficits [232] }\end{array}$ & $\begin{array}{l}\text { Reduced MK-801-increase in immobility } \\
\text { in forced swim test (FST) [230] } \\
\text { Attenuated MK-801-induced deficits in } \\
\text { social interaction [233, 234] } \\
\text { Rescued prenatal restraint-induced } \\
\text { deficits in social interaction [231] }\end{array}$ & $\begin{array}{l}\text { Reduced PCP-induced increase in errors, } \\
\text { but not accuracy, in the 5-choice serial } \\
\text { reaction time task (5CSRT) [235] } \\
\text { Exacerbated PCP-induced deficits in } \\
5 \text { CRST task [236] } \\
\text { Rescued MK-801-induced deficits in NOR } \\
{[234]} \\
\text { Reversed postnatal isolation-induced } \\
\text { deficits in NOR [232] }\end{array}$ \\
\hline \multicolumn{4}{|l|}{ mGlu 2 PAMs } \\
\hline LY487379 & $\begin{array}{l}\text { Reduced NMDAR-HL and AHL [141] } \\
\text { Attenuated AMP but not PCP-disrupted } \\
\text { PPI [141] }\end{array}$ & $\begin{array}{l}\text { Reduced PCP-induced deficits in social } \\
\text { interaction [229] }\end{array}$ & $\begin{array}{l}\text { Promoted cognitive flexibility in } \\
\text { attentional set-shift task (ASST) [237] }\end{array}$ \\
\hline BINA & $\begin{array}{l}\text { Reduced NMDAR-HL [149, 230] } \\
\text { No effect on AHL [149] } \\
\text { Reduced PCP-disrupted PPI [149] } \\
\text { Reduced DOB-induced head twitches } \\
\text { [150] }\end{array}$ & $\begin{array}{l}\text { Reduced MK-801-induced increased } \\
\text { immobility in the FST [230] }\end{array}$ & \\
\hline TASP0443294 & Reduced MHL [156] & $\begin{array}{l}\text { Rescued MK-801 induced social memory } \\
\text { deficits [156] }\end{array}$ & \\
\hline $\begin{array}{l}J N J-40411813 / \\
\text { ADX71149 }\end{array}$ & $\begin{array}{l}\text { Reduced NMDAR-HL [158] } \\
\text { No effect on AHL [158] } \\
\text { Inhibited DOM-induced head twitches } \\
\text { [158] }\end{array}$ & & \\
\hline SAR218645 & $\begin{array}{l}\text { No effect on NMDAR-HL or AHL [160] } \\
\text { No effect on hyperactivity in DAT }{ }^{-/-} \\
\text {and NR1 }{ }^{\text {neo- }-} \text { mice }[160] \\
\text { Reduced DOl-induced head twitches } \\
{[160]}\end{array}$ & & $\begin{array}{l}\text { Reversed MK-801-induced deficits in } \\
\text { NOR [160] } \\
\text { Attenuated working memory deficits in } \\
\text { Y-maze test in NR1 } 1^{\text {neo- }-} \text { mice }[160]\end{array}$ \\
\hline
\end{tabular}

randomly assigned to receive LY2140023, olanzapine, or placebo, LY2140023 showed statistically significant improvements in positive and negative symptoms (assessed by the Positive And Negative Symptom Scale, PANSS) relative to placebo and was comparable to the currently approved atypical antipsychotic olanzapine [136]. Most excitingly, this study found that LY2140023 was well-tolerated and did not produce any EPS or elevated prolactin levels [136].

Following these promising initial results, a second 4-week phase II dose-ranging study found that neither LY2140023 nor olanzapine was more efficacious than placebo. Thus, the results were inconclusive due to an abnormally high placebo effect [137]. In a subsequent 24 week phase II study LY2140023 was found to significantly reduce PANSS scores over the 24-week period but from weeks 16 to 24 it was less effective than the current standard of care group (treatment with olanzapine, aripiprazole, or risperidone) [138]. Discouragingly, in a larger phase II trial of 1013 patients, LY2140023 failed to show improvements in PANSS total score compared to placebo, while the atypical antipsychotic risperidone significantly separated from placebo [139]. A separate phase 1b study found that LY2140023 also failed to demonstrate efficacy in alleviating negative symptoms when administered concurrently with atypical antipsychotics although this has yet to be analyzed post-hoc based on prior patient antipsychotic use [140]. In response to these undesirable larger-scale clinical trial results, Eli Lilly and Co. terminated the development of LY2140023.

\section{mGlu, PAMs}

Although preclinical studies with group II mGlu agonists appeared promising, chronic administration of group II mGlu receptor agonists resulted in robust tolerance and loss of their ability to reverse amphetamine- and PCPinduced hyperlocomotion [141]. It is possible that this contributed to the lack of reliable clinical efficacy 
outlined above. Additionally, group II mGlu receptor agonists can impair working and spatial memory in rodent models [142, 143]. However, studies with $\mathrm{mGlu}_{2}$ and $\mathrm{mGlu}_{3}$ knockout mice suggest that the reversal of amphetamine- and PCP-induced hyperlocomotion by group II mGlu agonists was dependent on activation of $\mathrm{mGlu}_{2}$, not $\mathrm{mGlu}_{3}[144,145]$, prompting the development of $\mathrm{mGlu}_{2}$ selective PAMs. By potentiating responses to endogenous glutamate, it is possible that $\mathrm{mGlu}_{2}$ PAMs could reverse excessive glutamatergic signaling only at synapses where this pathophysiology is present, potentially avoiding the tolerance and cognition-impairing effects seen with orthosteric agonists and providing an alternative path forward for therapeutics targeting these receptors.

Two prototypical mGlu 2 PAMs, LY487379 [146, 147] and biphenyl-indanone A (BINA) [148, 149], showed efficacy in reversing amphetamine- and PCP-induced hyperlocomotion and disruptions in PPI (Table 2). Furthermore, BINA was able to attenuate the serotonininduced increase in excitatory transmission in the PFC and reduce head twitch behavior induced by the $5-\mathrm{HT}_{2 \mathrm{~A}}$ receptor agonist (-)-DOB [150]. Therefore, $\mathrm{mGlu}_{2}$ PAMs were efficacious in dopaminergic, glutamatergic, and serotonergic pharmacological models of the positive symptoms of schizophrenia. These studies provided foundational research which motivated multiple drug discovery programs to develop selective $\mathrm{mGlu}_{2}$ PAMs [151-155] that have efficacy in animal models of schizophrenia including TASP0443294 [156], JNJ-40411813/ ADX71149 [157, 158], AZD8529 [159], and SAR218645 [160] (Table 2).

TASP0443294 dose-dependently attenuated methamphetamine-induced hyperlocomotion, MK-801induced deficits in social memory, and ketamineinduced increases in cortical gamma power, as well as reducing the duration of REM sleep in rats [156]. JNJ-40411813/ADX71149 also dose-dependently inhibited PCP- and scopolamine-induced but intriguingly not amphetamine-induced hyperlocomotion. Furthermore, JNJ40411813/ADX71149 reduced brain glucose metabolism induced by the NMDAR antagonist memantine and head twitch response induced by the 5$\mathrm{HT}_{2 \mathrm{~A}}$ agonist DOM [158]. Recently, SAR218645 was shown to reduce DOI-induced cortical glutamate release and head twitch behavior but had no effect in pharmacological or genetic dopaminergic and glutamatergic models of the positive symptoms of schizophrenia [160]. SAR218645 did improve MK-801induced short-term episodic memory as well as working memory deficits in GluN1 knockdown mice, providing the first evidence of cognition-enhancing effects of $\mathrm{mGlu}_{2}$ PAMs in a genetic model of schizophrenia [160]. Based on these results, the authors suggested that $\mathrm{mGlu}_{2}$ PAMs with profiles like SAR218645 might be efficacious in treating the cognitive deficits in schizophrenia but not the positive symptoms [160].

To date, two $\mathrm{mGlu}_{2}$ PAMs have progressed to clinical trials: JNJ40411813/ADX71149 [161] and AZD8529 [159]. Phase I assessment in healthy volunteers indicated that JNJ40411813 was generally well tolerated in healthy men and women-with adverse events such as ataxia and somnolence emerging only at high doses [161]. However, secondary measures of cognition endpoints suggested that the $\mathrm{mGlu}_{2}$ PAM decreased accuracy in an attention task in healthy men. Although, JNJ40411813 did trend to reduce cognitive deficits in attention and episodic memory precipitated by smoking withdrawal in a subpopulation of healthy volunteers, this was not statistically significant compared to placebo. Promisingly in a proportion of volunteers, $500 \mathrm{mg}$ JNJ40411813 reduced the increase in Brief Psychiatric Rating Scale (BPRS) total score and negative symptom score induced by a low dose of (S)-ketamine [161]. Based on its tolerability and promising initial results in the ketamine challenge, it will be interesting to see if Johnson \& Johnson will progress the compound further.

Recently, the phase II trial results of AstraZeneca's $\mathrm{mGlu}_{2}$ PAM AZD8529 were disclosed [159]. Despite being well tolerated with mild adverse events, AZD8529 did not show any improvements in PANSS total score or PANSS positive and negative subscale scores compared to placebo. While AZD8529 did not produce any extrapyramidal side effects or elevation of prolactin (an effect observed with the comparator risperidone) it failed to demonstrate efficacy in this study of 104 patients with schizophrenia [159]. Possible explanations for this lack of efficacy include lack of sufficient target engagement and the use of a less symptomatic patient population. However, CNS activity suggesting target engagement was subsequently validated using fMRI, and risperidone significantly improved PANSS scores compared to placebo, suggesting that this $\mathrm{mGlu}_{2}$ PAM may lack sufficient efficacy even at doses that provide CNS effects [159].

Together with the disappointing results of the group II agonist LY2140023 trials, there is a significant discrepancy between these preclinical data implicating glutamatergic dysfunction and $\mathrm{mGlu}_{2}$ agonist or PAM efficacy and these clinical data. This could be in part due to improper patient selection, as hyperactivity of cortical regions correlates with psychosis only early on in disease progression $[162,163]$. Furthermore, since atypical antipsychotics may decrease $\mathrm{mGlu}_{2}$ levels via the $5 \mathrm{HT}_{2 \mathrm{~A}} /$ $\mathrm{mGlu}_{2}$ heteromer [126], lower receptor levels might contribute to the lack of efficacy in the patient populations used in either study. While an intriguing possibility, this remains to be tested. 
$\mathrm{mGlu}_{3}$

While pharmacological manipulation of group II mGlu receptors was based on the normalization of aberrant glutamatergic signaling downstream of NMDAR hypofunction, single nucleotide polymorphisms (SNPs) in the GRM3 gene encoding $\mathrm{mGlu}_{3}$ have been associated with schizophrenia in multiple studies [164-167]. No studies to date have found statistically significant associations with GRM2 SNPs [168, 169]. The association between GRM3 and schizophrenia has been extensively reviewed in the past, with certain SNPs associated with deficits in working and episodic memory [166]. More recently, a large-scale genome-wide association study of almost 37,000 patients with schizophrenia identified the GRM3 locus, as well as 108 other loci, associated with schizophrenia [170], supporting the idea that $\mathrm{mGlu}_{3}$ may be a viable target along with $\mathrm{mGlu}_{2}$, despite the antipsychoticlike efficacy of $\mathrm{mGlu}_{2}$ specific potentiators in rodent models.

Supporting this, a recent study using the $\mathrm{mGlu}_{2}$ agonist/mGlu $\mathrm{m}_{3}$ antagonist LY395756 [171] showed that $\mathrm{mGlu}_{2}$ agonism was sufficient to enhance NMDAR function but the combination of $\mathrm{mGlu}_{2}$ agonism and $\mathrm{mGlu}_{3}$ antagonism could not reverse MK801-induced deficits in working memory [172]. This is consistent with the finding that $\mathrm{mGlu}_{3}$ is required for a form of LTD in the mouse PFC and that a selective $\mathrm{mGlu}_{3}$ negative allosteric modulator impairs PFC-dependent cognition [173]. Based on these findings and the neuroprotective role of $\mathrm{mGlu}_{3}$ [174-177], agonism or enhancement of $\mathrm{mGlu}_{3}$ signaling may provide pro-cognitive benefits in addition to ameliorating some of the neuroinflammatory pathology seen in schizophrenia $[178,179]$. Finally, it has recently been reported that $\mathrm{mGlu}_{3}$ activation can positively modulate $\mathrm{mGlu}_{5}$ signaling [180], providing a potential mechanism to enhance NMDAR function (via $\mathrm{mGlu}_{3}-\mathrm{mGlu}_{5}$-NMDAR interactions) and consequently provide both antipsychotic and pro-cognitive efficacy. Though this hypothesis remains to be tested, the biological role and preclinical pharmacology indicate that enhancement of $\mathrm{mGlu}_{3}$ might be a promising strategy for the treatment of schizophrenia, especially with potential for improving cognitive disturbances in patients with schizophrenia.

\section{Group III mGlu receptors ( $\mathrm{mGlu}_{4}, \mathrm{mGlu}_{7}, \& \mathrm{mGlu}_{8}$ )}

The group III mGlu receptors are grouped based on high sequence homology and consist of $\mathrm{mGlu}_{4}$ [103], $\mathrm{mGlu}_{6}[181], \mathrm{mGlu}_{7}[182]$, and $\mathrm{mGlu}_{8}[22,183] . \mathrm{mGlu}_{6}$ is expressed exclusively in the retina, whereas the other group III mGlu receptors are primarily expressed in the CNS [181]. Similar to group II, group III mGlu receptors canonically signal via the $G \alpha_{i / o}$ subunits of the heterotrimeric G-protein complex, leading to inhibition of adenylyl cyclase and cAMP production [22]. Activation of group III mGlu receptors can also regulate neurotransmitter release via activation/inhibition of different ion channels and $\mathrm{G}_{\beta \mathrm{Y}}$-dependent inhibition of vesicular fusion [184]. Akin to the group II mGlu receptors, the therapeutic promise of group III mGlu receptor activators or potentiators arises from their hypothesized ability to ameliorate the hyperglutamatergic state proposed to take place in schizophrenia. Also, group III mGlu receptor activation reduces dopamine release in the nucleus accumbens [64] but more work is needed to ascertain if this reduction of dopamine release would contribute to potential antipsychotic efficacy of group III mGlu receptor agonists and/or PAMs.

\section{$\mathrm{mGlu}_{4}$}

$\mathrm{mGlu}_{4}$ is expressed predominantly on presynaptic glutamatergic and GABAergic terminals [22] (Fig. 1). In multiple immunohistochemistry studies, $\mathrm{mGlu}_{4}$ has been shown to localize to the presynaptic active zone, where it is situated to function as an auto- and heteroreceptor upon the release of glutamate into the synaptic cleft $[185,186] . \mathrm{mGlu}_{4}$ is highly expressed in the cerebellum, moderately expressed in the olfactory bulb and thalamus, and lowly expressed in the hippocampus and the striatum [187]. Likely due to high levels of $\mathrm{mGlu}_{4}$ in the cerebellum, $\mathrm{mGlu}_{4} \mathrm{KO}$ mice have deficits in cerebellar synaptic plasticity and impaired ability to learn complicated motor tasks [188]. Mice lacking $\mathrm{mGlu}_{4}$ also display deficits in spatial reversal and long-term memory [189], indicating a role of $\mathrm{mGlu}_{4}$ in cognition and cognitive flexibility, both of which are impaired in schizophrenia.

Multiple studies suggest that activation of $\mathrm{mGlu}_{4}$ may have antipsychotic-like effects in rodent models (Table 3). The pan-group III agonist ACPT-I reduced PCP- and amphetamine-induced hyperlocomotion as well as DOIinduced head twitches [190], and these actions of ACPT-I are also observed with $\mathrm{mGlu}_{4}$-selective agonists, LSP1-2111 [191] (>30-fold selective for $\mathrm{mGlu}_{4}$ vs. $\mathrm{mGlu}_{8}$ ) and LSP4-2022 [192] (>100-fold selective for $\mathrm{mGlu}_{4}$ vs. $\mathrm{mGlu}_{7} ;>300$-fold vs. $\left.\mathrm{mGlu}_{8}\right)$. In addition to efficacy in models of the positive symptoms of schizophrenia, both LSP1-2111 and LSP4-2022 have efficacy in models of negative symptoms and cognitive deficits [191, 192]. Furthermore, the $\mathrm{mGlu}_{4}$-selective PAMs Lu AF21934 [193], Lu AF32615 [194], and ADX88178 [195] displayed similar promise in models of all three symptom clusters of schizophrenia [196, 197], providing further support for potential therapeutic utility of selective $\mathrm{mGlu}_{4}$ activators.

Interestingly, recent studies raise the possibility that some of the in vivo actions of $\mathrm{mGlu}_{4}$ agonists or PAMs could be mediated by actions on $\mathrm{mGlu}_{2 / 4}$ heterodimers (Fig. 2b). While mGlu receptors are thought to function 
Table 3 Summary of Preclinical Efficacy of Group III mGlu Receptor Ligands

\begin{tabular}{|c|c|c|c|}
\hline & Positive Symptom Models & Negative Symptom Models & Cognition Models \\
\hline \multicolumn{4}{|l|}{ Group III agonist } \\
\hline ACPT-I & $\begin{array}{l}\text { Reduced NMDAR-HL and AHL [190] } \\
\text { Reduced DOI-induced head twitches [190] }\end{array}$ & & \\
\hline \multicolumn{4}{|l|}{$\mathrm{mGlu}_{4}$ agonists } \\
\hline LSP1-2111 & $\begin{array}{l}\text { Reduced NMDAR-HL and AHL [191] } \\
\text { Reduced DOl-induced head twitches [191] }\end{array}$ & & \\
\hline LSP4-2022 & $\begin{array}{l}\text { Reduced NMDAR-HL [192] } \\
\text { Reduced DOl-induced head twitches [192] }\end{array}$ & $\begin{array}{l}\text { Reduced MK-801-induced deficits in } \\
\text { social interaction [192] }\end{array}$ & $\begin{array}{l}\text { Reduced MK-801-induced deficits in } \\
\text { NOR [192] }\end{array}$ \\
\hline \multicolumn{4}{|l|}{$\mathrm{mGlu}_{4}$ PAMs } \\
\hline Lu AF21934 & $\begin{array}{l}\text { Reduced NMDAR-HL and AHL }[196,238] \\
\text { Reduced DOI-induced head twitches }[196,238]\end{array}$ & $\begin{array}{l}\text { Reduced MK-801-induced deficits in } \\
\text { social interaction }[196,238]\end{array}$ & $\begin{array}{l}\text { Rescued MK-801-induced deficits in the } \\
\text { delayed spatial alternation task [196] } \\
\text { Reduced MK-801-induced deficits in } \\
\text { NOR [238] }\end{array}$ \\
\hline Lu AF32615 & $\begin{array}{l}\text { Reduced NMDAR-HL and AHL [196] } \\
\text { Reduced DOI-induced head twitches [196] }\end{array}$ & $\begin{array}{l}\text { Reduced MK-801-induced deficits in } \\
\text { social interaction [196] }\end{array}$ & $\begin{array}{l}\text { Rescued MK-801-induced deficits in } \\
\text { the delayed spatial alternation task [196] }\end{array}$ \\
\hline ADX88178 & $\begin{array}{l}\text { Reduced NMDAR-HL [197] } \\
\text { Reduced DOI-induced head twitches [197] }\end{array}$ & Reduced immobility in FST [197] & \\
\hline \multicolumn{4}{|l|}{$m G l u>$ agonist } \\
\hline AMN082 & $\begin{array}{l}\text { Exacerbated NMDAR-HL [191] } \\
\text { No effect on AHL [191] } \\
\text { Exacerbated DOI-induced head twitches [191] }\end{array}$ & & \\
\hline \multicolumn{4}{|l|}{$m G / u_{8}$ agonist } \\
\hline (S)-3,4-DCPG & No effect on NMDAR-HL or AHL [221] & & \\
\hline
\end{tabular}

primarily as homodimers [198], in recent years it has become apparent that functional mGlu heterodimers exist and can have unique profiles in terms of altered signaling and pharmacology [199-201]. Recent studies reveal that a heterodimer between $\mathrm{mGlu}_{2}$ and $\mathrm{mGlu}_{4}$ exists and displays unique pharmacology compared to $\mathrm{mGlu}_{2}$ or $\mathrm{mGlu}_{4}$ homodimers $[201,202]$. Interestingly, $\mathrm{mGlu}_{2 / 4}$ heterodimers are activated by orthosteric agonists of either $\mathrm{mGlu}_{2 / 3}$ or $\mathrm{mGlu}_{4}$ [201]. Furthermore, Lu AF21934, an $\mathrm{mGlu}_{4}$ PAM that has efficacy in rodent models of antipsychotic-like effects, has robust efficacy as an mGlu $_{2 / 4}$ heterodimer PAM (Fig. 2b). Thus, while studies have yet to directly test the hypothesis that $\mathrm{mGlu}_{2 / 4}$ heterodimers are involved in the antipsychotic-like effects of these compounds, it will be important to consider this possibility in future studies.

$\mathrm{mGlu}_{7}$

A polymorphism in the GRM7 gene encoding $\mathrm{mGlu}_{7}$ that reduced transcription in vitro was found to be positively associated with schizophrenia in a large Japanese cohort [203], indicating that hypofunction of $\mathrm{mGlu}_{7}$ may contribute to this disorder. However, at present, few studies have focused on a potential role of $\mathrm{mGlu}_{7}$ in the pathophysiology of schizophrenia. Interestingly, $\mathrm{mGlu}_{7}$ exhibits the widest expression of group III receptors [187, 204], with high expression in cortex, hippocampus, and other forebrain regions [205]. Studies with mGlu
KO mice demonstrated a role of $\mathrm{mGlu}_{7}$ in hippocampal short-term plasticity [206], amygdala-dependent learning processes [206], short-term working memory [207, 208], and extinction learning $[208,209]$. Also, activation of $\mathrm{mGlu}_{7}$ reduces glutamatergic neurotransmission at the SC-CA1 synapse in the hippocampus $[210,211]$ and acts as a heteroreceptor (Fig. 1) to modulate GABA release and the induction of LTP at SC-CA1 [212]. Thus, selective activators of $\mathrm{mGlu}_{7}$ have the potential to enhance some aspects of hippocampal-dependent cognitive function. In addition, evidence suggests that $\mathrm{mGlu}_{7}$ activation reduces thalamocortical neurotransmission [213], a circuit thought to be overactive in schizophrenia [214]. However, the $\mathrm{mGlu}_{7}$ allosteric agonist AMN082 [215] exacerbates MK-801-induced hyperlocomotion and DOI-induced head twitches [191] (Table 3). While this may be due to off-target effects of AMN082 or its metabolites in vivo [216], these pro-psychotic effects were absent in $\mathrm{mGlu}_{7}$ KO mice [191] suggesting that they are mediated by $\mathrm{mGlu}_{7}$. It remains to be seen if the same pro-psychotic effects are observed using selective PAMs and future studies are needed to fully evaluate the potential utility of $\mathrm{mGlu}_{7}$ agonists or PAMs in schizophrenia-related models.

\section{$\mathrm{mGlu}_{8}$}

mGlu $_{8}$ is widely expressed throughout the brain, although at relatively low levels compared to other group III mGlu receptors [22]. Like $\mathrm{mGlu}_{4}$ and $\mathrm{mGlu}_{7}, \mathrm{mGlu}_{8}$ 
is expressed in the presynaptic active zone of mainly glutamatergic synapses [185, 217] (Fig. 1) where it functions to modulate neurotransmitter release. It has also been identified in the postsynaptic compartment in the retina, medulla, and periphery [205]. $\mathrm{mGlu}_{8}$ has been shown to function as an autoreceptor at the lateral perforant path synapse in the dentate gyrus [218], thus gating glutamatergic transmission into the hippocampus. Consistent with this, $\mathrm{mGlu}_{8} \mathrm{KO}$ mice display deficits in hippocampaldependent learning [219]. Additionally, $\mathrm{mGlu}_{8}$ suppresses glutamatergic input into the bed nucleus of the stria terminalis (BNST) implicating a role for this receptor in anxiety and stress [220], consistent with results observed in the $\mathrm{mGlu}_{8} \mathrm{KO}$ mice [221]. Similar to both $\mathrm{mGlu}_{4}$ and $\mathrm{mGlu}_{7}$, the neuromodulatory role of $\mathrm{mGlu}_{8}$ in brain regions implicated in learning and memory suggests that $\mathrm{mGlu}_{8}$ ligands could be beneficial in treating the cognitive deficits in patients with schizophrenia.

In studies investigating the potential antipsychotic efficacy of targeting $\mathrm{mGlu}_{8}$, researchers from GlaxoSmithKline found that the relatively selective orthosteric $\mathrm{mGlu}_{8}$ agonist (S)-3,4-DCPG [222] was unable to reverse PCPinduced or amphetamine-induced hyperactivity in Sprague-Dawley rats [221] (Table 3). Furthermore, mGlu $_{8} \mathrm{KO}$ mice had no significant deficits in PPI and thus it was concluded that $\mathrm{mGlu}_{8}$ does not appear to be involved in the etiology of schizophrenia nor does it appear to be a potential target for a novel antipsychotic [221]. This may be true with respect to positive symptoms but, based on the role mGlu 8 plays in hippocampal neurotransmission $[218,221]$ it is still possible that agonists or potentiators of $\mathrm{mGlu}_{8}$ can have cognitiveenhancing properties. While exciting, this remains to be tested.

\section{Conclusion}

Extensive preclinical evidence has implicated all three groups of mGlu receptors as viable targets for the development of novel therapeutics for the treatment of schizophrenia. Agonists and subtype-selective PAMs for these receptors have efficacy in dopaminergic, serotonergic, and glutamatergic models of the positive and negative symptoms of the disease, and also demonstrate nootropic, or cognition-enhancing effects (Tables 1, 2, and 3). Based on preclinical findings, mGlu receptor modulators have the potential to be major improvements over currently approved dopaminergic and serotonergic antipsychotics. Negative results in clinical trials for the group II agonist pomaglumetad (LY2140023) and

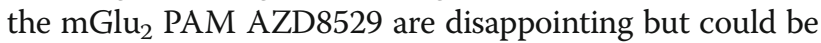
explained by patient selection issues. Potential future trials with patients selected based on stage of the disease and prior antipsychotic usage may yield different results in light of our advanced knowledge of the pathophysiology of schizophrenia. These negative clinical results suggest that there are still important gaps in our knowledge of how to translate preclinical results into clinical efficacy in schizophrenia. Taken together, these studies point to potential challenges in selecting the most appropriate patient populations for evaluating different mechanisms for improving different symptoms observed in schizophrenia patients.

In addition to potential antipsychotic efficacy, selective mGlu receptor ligands could provide cognition-enhancing effects targeting a major unmet need of this disorder. To this end, the key role of $\mathrm{mGlu}_{5}$ in hippocampal and cortical plasticity suggests that mGlu ${ }_{5}$ PAMs might have their greatest effects on cognition. Furthermore, the interaction between $\mathrm{mGlu}_{3}$ and $\mathrm{mGlu}_{5}$ and the involvement of $\mathrm{mGlu}_{3}$ in cortical plasticity suggests that potentiators of $\mathrm{mGlu}_{3}$ may also exert cognition-enhancing effects. Lastly, the notion that mGlu receptor ligands would provide a powerful cognition-enhancing approach to mitigate the deficits observed in schizophrenia is further evidenced by the $\mathrm{mGlu}_{2}$ PAM SAR218645 improving learning and memory in rodent models of schizophrenia as well as the preclinical cognition-enhancement observed with $\mathrm{mGlu}_{4}$ agonists and PAMs.

Of particular importance to future development efforts, both the discovery of biased PAMs (Fig. 2a) and the existence of mGlu heterodimers with distinct pharmacology (Fig. 2b) could provide novel approaches to optimize efficacy while avoiding toxic or other adverse effects. Although relatively unexplored, these emerging concepts in the pharmacology and biology of mGlu receptors provide a new path forward in the face of negative clinical results.

In conclusion, the metabotropic glutamate receptors represent a large group of promising targets for novel therapeutics to treat all three symptom domains of schizophrenia. While many discovery efforts are still in preclinical phases of development, they have yielded several subtype-selective tool compounds with minimal adverse effect profiles and promising preclinical efficacy. These compounds provide the unprecedented opportunity to further our fundamental understanding of the therapeutic role of mGlu receptor modulation in schizophrenia and represent a potential breakthrough in treating patients suffering from this disorder.

\section{Abbreviations}

5CSRT: 5-choice serial reaction time; 5-HIAA: 5-Hydroxyindoleacetic acid; 5-HT $2 \mathrm{~A}$ R: Serotonin (5-hydroxytryptamine) $2 \mathrm{~A}$ receptor; AHL: Amphetamineinduced hyperlocomotion; AMP: Amphetamine; AMPA: a-amino-3-hydroxy-

5-methyl-4-isoxazolepropionic acid; ASST: Attentional set-shift task; BNST: Bed nucleus of the stria terminalis; BPRS: Brief Psychiatric Rating Scale;

CF: Conditioned fear; CNS: Central nervous system; DAG: Diacylglycerol; DMPK: Drug metabolism and pharmacokinetics; DMTP: Delayed matching to position; DNMTP: Delayed non-matching to position; DOPAC: 3, 4Dihydroxyphenylacetic acid; DTDA: Discrete-trial delayed alternation; EPS: Extrapyramidal side effects; FST: Forced swim test; GABA: $\gamma$-amino 
butyric acid; GPCR: G-protein coupled receptor; HL: Hyperlocomotion; HVA: Homovanillic Acid; IP 3 : inositol triphosphate; KET: Ketamine; KO: Knockout; LTD: Long term depression; LTP: Long term potentiation; METH: Methamphetamine; mGlu: Metabotropic glutamate; $\mathrm{MHL}$ : Methamphetamine-induced hyperlocomotion; MWM: Morris water maze; NAM: Negative allosteric modulator; NMDAR: N-methyl-D-aspartate receptor; NMDAR-HL: NMDAR antagonist-induced hyperlocomotion; NOR: Novel object recognition; OLM: Object location memory; PAM: Positive allosteric modulator; PANSS: Positive and Negative Symptom Scale; PCP: Phencyclidine; PFC: Prefrontal cortex; PKC: Protein kinase C; PPI: Prepulse inhibition; SNP: Single nucleotide polymorphism; $\mathrm{SR}^{-1-}$ : Serine racemase knockout

\section{Acknowledgements}

We would like to sincerely thank Max E Joffe for critically reviewing the manuscript.

\section{Funding}

JM has received funding from the Vanderbilt International Scholars Program and is a recipient of a Canadian Institutes of Health Research Doctoral Foreign Study Award (DFS146189). SPM receives funding from a Vanderbilt Training in Fundamental Neuroscience fellowship T32 (MH64913) and the Vanderbilt Clinical Neuroscience Scholars Program. PJC receives funding from the National Institute of Mental Health (MH062646) and the National Institute of Neurological Disease and Stroke (NS031373).

\section{Availability of data and materials}

Not applicable.

\section{Authors' contributions}

$J M, S P M$, and PJC contributed to the writing and revision of the manuscript. All authors read and approved the final manuscript.

\section{Competing interests}

PJC is an inventor on multiple composition of matter patents protecting allosteric modulators of GPCRs. JM and SPM declare that they have no competing interests.

\section{Consent for publication}

Not applicable.

Ethics approval and consent to participate Not applicable.

\section{Publisher's Note}

Springer Nature remains neutral with regard to jurisdictional claims in published maps and institutional affiliations.

\section{Author details}

'Department of Pharmacology, Vanderbilt University, Nashville, TN 37232, USA. ${ }^{2}$ Vanderbilt Center for Neuroscience Drug Discovery, Nashville, TN 37232, USA. ${ }^{3}$ Vanderbilt Brain Institute, Vanderbilt University, Nashville, TN 37232, USA.

Received: 1 December 2016 Accepted: 4 April 2017 Published online: 26 April 2017

\section{References}

1. van Os J, Kapur S. Schizophrenia. Lancet. 2009;374:635-45.

2. Association AP. Diagnostic and Statistical Manual of Mental Disorders, Fourth Edition: DSM-IV-TR ${ }^{\oplus}$. American Psychiatric Association. 2000.

3. Green MF. What are the functional consequences of neurocognitive deficits in schizophrenia? Am J Psychiatry. 1996;153:321-30.

4. Bobes J, Garcia-Portilla MP, Bascaran MT, Saiz PA, Bouzoño M. Quality of life in schizophrenic patients. Dialogues Clin Neurosci. 2007;9:215-26.

5. McEvoy JP. The costs of schizophrenia. J Clin Psychiatry. 2007;68 Suppl 14:4-7.

6. Lieberman JA, Stroup TS, McEvoy JP, Swartz MS, Rosenheck RA, Perkins DO, Keefe RSE, Davis SM, Davis CE, Lebowitz BD, et al. Effectiveness of Antipsychotic Drugs in Patients with Chronic Schizophrenia. N Engl J Med. 2005;353:1209-23.
7. Meltzer HY. Update on Typical and Atypical Antipsychotic Drugs. Annu Rev Med. 2013;64:393-406.

8. Lally J, MacCabe $\mathrm{JH}$. Antipsychotic medication in schizophrenia: a review. $\mathrm{Br}$ Med Bull. 2015;114:169-79.

9. Coyle JT. Glutamate and Schizophrenia: Beyond the Dopamine Hypothesis. Cell Mol Neurobiol. 2006:26:363-82.

10. Moghaddam B, Javitt D. From Revolution to Evolution: The Glutamate Hypothesis of Schizophrenia and its Implication for Treatment. Neuropsychopharmacology. 2012;37:4-15.

11. Anis NA, Berry SC, Burton NR, Lodge D. The dissociative anaesthetics, ketamine and phencyclidine, selectively reduce excitation of central mammalian neurones by N-methyl-aspartate. Br J Pharmacol. 1983;79: 565-75.

12. EF D, ED L. Abnormal mental states induced by phencyclidine as a model of schizophrenia. In: Domino E, editor. Phencyclidine: Historical and Current Perspectives. Ann Arbor: NPP Books; 1981. p. 401-18.

13. Cosgrove J, Newell TG. Recovery of neuropsychological functions during reduction in use of phencyclidine. J Clin Psychol. 1991;47:159-69.

14. Javitt DC, Zukin SR. Recent advances in the phencyclidine model of schizophrenia. Am J Psychiatry. 1991;148:1301-8.

15. Krystal JH, Karper LP, Seibyl JP, et al. Subanesthetic effects of the noncompetitive nmda antagonist, ketamine, in humans: Psychotomimetic, perceptual, cognitive, and neuroendocrine responses. Arch Gen Psychiatry. 1994;51:199-214.

16. Zeron MM, Hansson O, Chen N, Wellington CL, Leavitt BR, Brundin P, Hayden MR, Raymond LA. Increased Sensitivity to N-Methyl-D-Aspartate Receptor-Mediated Excitotoxicity in a Mouse Model of Huntington's Disease. Neuron. 2002:33:849-60.

17. Monaghan DT, Irvine MW, Costa BM, Fang G, Jane DE. Pharmacological modulation of NMDA receptor activity and the advent of negative and positive allosteric modulators. Neurochem Int. 2012;61:581-92.

18. Puddifoot C, Martel M-A, Soriano FX, Camacho A, Vidal-Puig A, Wyllie DJA, Hardingham GE. PGC-1 a negatively regulates extrasynaptic NMDAR activity and excitotoxicity. J Neurosci. 2012;32:6995-7000.

19. Kaufman AM, Milnerwood AJ, Sepers MD, Coquinco A, She K, Wang L, Lee $\mathrm{H}$, Craig AM, Cynader M, Raymond LA. Opposing Roles of Synaptic and Extrasynaptic NMDA Receptor Signaling in Cocultured Striatal and Cortical Neurons. J Neurosci. 2012;32:3992-4003.

20. Hackos DH, Lupardus PJ, Grand T, Chen Y, Wang T-M, Reynen P, Gustafson A. Wallweber HJA, Volgraf M, Sellers BD. Positive allosteric modulators of GluN2A-containing NMDARs with distinct modes of action and impacts on circuit function. Neuron. 2016;89(5):983-99.

21. Iwata Y, Nakajima S, Suzuki T, Keefe RSE, Plitman E, Chung JK, Caravaggio F, Mimura M, Graff-Guerrero A, Uchida H. Effects of glutamate positive modulators on cognitive deficits in schizophrenia: a systematic review and meta-analysis of double-blind randomized controlled trials. Mol Psychiatry. 2015;20:1151-60.

22. Niswender CM, Conn PJ. Metabotropic Glutamate Receptors: Physiology, Pharmacology, and Disease. Annu Rev Pharmacol Toxicol. 2010;50:295-322.

23. Wu H, Wang C, Gregory KJ, Han GW, Cho HP, Xia Y, Niswender CM, Katritch V, Meiler J, Cherezov V, et al. Structure of a Class C GPCR Metabotropic Glutamate Receptor 1 Bound to an Allosteric Modulator. Science. 2014;344: 58-64.

24. Hemstapat $K$, Costa HD, Nong Y, Brady AE, Luo Q, Niswender CM, Tamagnan GD, Conn PJ. A Novel Family of Potent Negative Allosteric Modulators of Group II Metabotropic Glutamate Receptors. J Pharmacol Exp Ther. 2007;322:254-64.

25. Christopher JA, Aves SJ, Bennett KA, Doré AS, Errey JC, Jazayeri A, Marshall FH, Okrasa K, Serrano-Vega MJ, Tehan BG, et al. Fragment and StructureBased Drug Discovery for a Class C GPCR: Discovery of the mGlu5 Negative Allosteric Modulator HTL14242 (3-Chloro-5-[6-(5-fluoropyridin-2-yl)pyrimidin4-yl]benzonitrile). J Med Chem. 2015;58:6653-64.

26. Houamed K, Kuijper J, Gilbert T, Haldeman B, O'Hara P, Mulvihill E, Almers W, Hagen F. Cloning, expression, and gene structure of a G protein-coupled glutamate receptor from rat brain. Science. 1991;252:1318-21.

27. Masu M, Tanabe Y, Tsuchida K, Shigemoto R, Nakanishi S. Sequence and expression of a metabotropic glutamate receptor. Nature. 1991;349:760-5.

28. Abe T, Sugihara H, Nawa H, Shigemoto R, Mizuno N, Nakanishi S. Molecular characterization of a novel metabotropic glutamate receptor mGluR5 coupled to inositol phosphate/Ca2+ signal transduction. J Biol Chem. 1992; 267:13361-8. 
29. Aniksztejn L, Bregestovski P, Ben-Ari Y. Selective activation of quisqualate metabotropic receptor potentiates NMDA but not AMPA responses. Eur J Pharmacol. 1991;205:327-8

30. Harvey J, Collingridge GL. Signal transduction pathways involved in the acute potentiation of NMDA responses by 1S, 3R-ACPD in rat hippocampal slices. Br J Pharmacol. 1993;109:1085-90.

31. Yu SP, Sensi SL, Canzoniero LM, Buisson A, Choi DW. Membrane-delimited modulation of NMDA currents by metabotropic glutamate receptor subtypes 1/5 in cultured mouse cortical neurons. J Physiol. 1997;499:721-32.

32. Fitzjohn SM, Irving AJ, Palmer MJ, Harvey J, Lodge D, Collingridge GL. Activation of group I mGluRs potentiates NMDA responses in rat hippocampal slices. Neurosci Lett. 1996;203:211-3.

33. Higley MJ. Localized GABAergic inhibition of dendritic Ca2+ signalling. Nat Rev Neurosci. 2014;15:567-72.

34. Romano C, Van den Pol AN, O'Malley KL. Enhanced early developmental expression of the metabotropic glutamate receptor mGluR5 in rat brain: Protein, mRNA splice variants, and regional distribution. J Comp Neurol. 1996;367:403-12.

35. Lum JS, Fernandez F, Matosin N, Andrews JL, Huang X-F, Ooi L, Newell KA. Neurodevelopmental Expression Profile of Dimeric and Monomeric Group 1 mGluRs: Relevance to Schizophrenia Pathogenesis and Treatment. Sci Rep. 2016;6:34391.

36. Frank RAW, McRae AF, Pocklington AJ, van de Lagemaat $L N$, Navarro $P$, Croning MDR, Komiyama NH, Bradley SJ, Challiss JRA, Armstrong DJ, et al. Clustered Coding Variants in the Glutamate Receptor Complexes of Individuals with Schizophrenia and Bipolar Disorder. PLoS One. 2011;6(4): e19011.

37. Ayoub M, Angelicheva D, Vile D, Chandler D, Morar B, Cavanaugh JA, Visscher PM, Jablensky A, Pfleger KDG, Kalaydjieva L. Deleterious GRM1 Mutations in Schizophrenia. PLoS One. 2012;7(3):e32849.

38. Volk DW, Eggan SM, Lewis DA. Alterations in metabotropic glutamate receptor 1 and regulator of $G$ protein signaling 4 in the prefrontal cortex in schizophrenia. Am J Psychiatry. 2010;167(12):1489-98.

39. Brody SA, Conquet F, Geyer MA. Disruption of prepulse inhibition in mice lacking mGluR1. Eur J Neurosci. 2003;18(12):3361-6.

40. Javanbakht A. Sensory gating deficits, pattern completion, and disturbed fronto-limbic balance, a model for description of hallucinations and delusions in schizophrenia. Med Hypotheses. 2006;67:1173-84.

41. Cho HP, Garcia-Barrantes PM, Brogan JT, Hopkins CR, Niswender CM, Rodriguez AL, Venable DF, Morrison RD, Bubser M, Daniels SJ, et al. Chemical Modulation of Mutant mGlu1 Receptors Derived from Deleterious GRM1 Mutations Found in Schizophrenics. ACS Chem Biol. 2014:9:2334-46.

42. Davis KL, Kahn RS, Ko G, Davidson M. Dopamine in schizophrenia: a review and reconceptualization. Am J Psychiatry. 1991;148:1474-86.

43. Laruelle M, Abi-Dargham A, Gil R, Kegeles L, Innis R. Increased dopamine transmission in schizophrenia: relationship to illness phases. Biol Psychiatry. 1999:46:56-72.

44. Abi-Dargham A, Rodenhiser J, Printz D, Zea-Ponce Y, Gil R, Kegeles LS, Weiss R, Cooper TB, Mann JJ, Van Heertum RL, et al. Increased baseline occupancy of D2 receptors by dopamine in schizophrenia. Proc Natl Acad Sci. 2000;97: 8104-9.

45. Howes OD, Montgomery AJ, Asselin M, et al. Elevated striatal dopamine function linked to prodromal signs of schizophrenia. Arch Gen Psychiatry. 2009;66:13-20

46. Verma A, Moghaddam B. Regulation of striatal dopamine release by metabotropic glutamate receptors. Synapse. 1998;28:220-6.

47. Campusano JM, Abarca J, Forray Ml, Gysling K, Bustos G. Modulation of dendritic release of dopamine by metabotropic glutamate receptors in rat substantia nigra. Biochem Pharmacol. 2002;63:1343-52.

48. Chaki S, Yoshikawa R, Okuyama S. Group II metabotropic glutamate receptor-mediated regulation of dopamine release from slices of rat nucleus accumbens. Neurosci Lett. 2006:404:182-6.

49. Zhang H, Sulzer D. Glutamate Spillover in the Striatum Depresses Dopaminergic Transmission by Activating Group I Metabotropic Glutamate Receptors. J Neurosci. 2003;23:10585-92.

50. Knoflach F, Mutel V, Jolidon S, Kew JNC, Malherbe P, Vieira E, Wichmann J, Kemp JA. Positive allosteric modulators of metabotropic glutamate 1 receptor: Characterization, mechanism of action, and binding site. Proc Natl Acad Sci. 2001;98:13402-7.

51. Vieira E, Huwyler J, Jolidon S, Knoflach F, Mutel V, Wichmann J. $9 \mathrm{H}$ Xanthene-9-carboxylic acid [1,2,4]oxadiazol-3-yl- and (2H-tetrazol-5-yl)- amides as potent, orally available mGlu1 receptor enhancers. Bioorg Med Chem Lett. 2005;15:4628-31.

52. Garcia-Barrantes PM, Cho HP, Blobaum AL, Niswender CM, Conn JP, Lindsley CW. Lead optimization of the VU0486321 series of mGlu1 PAMs. Part 1: SAR of modifications to the central aryl core. Bioorg Med Chem Lett. 2015;25: 5107-10.

53. Garcia-Barrantes PM, Cho HP, Blobaum AL, Niswender CM, Conn JP, Lindsley CW. Lead optimization of the VU0486321 series of mGlu1 PAMs. Part 3. Engineering plasma stability by discovery and optimization of isoindolinone analogs. Bioorg Med Chem Lett. 2016;26:1869-72.

54. Garcia-Barrantes PM, Cho HP, Metts AM, Blobaum AL, Niswender CM, Conn JP, Lindsley CW. Lead optimization of the VU0486321 series of mGlu1 PAMs. Part 2: SAR of alternative 3-methyl heterocycles and progress towards an in vivo tool. Bioorg Med Chem Lett. 2016;26:751-6.

55. Garcia-Barrantes PM, Cho HP, Starr TM, Blobaum AL, Niswender CM, Conn JP, Lindsley CW. Re-exploration of the mGlu1 PAM Ro 07-11401 scaffold: Discovery of analogs with improved CNS penetration despite steep SAR. Bioorg Med Chem Lett. 2016;26:2289-92.

56. Satow A, Maehara S, Ise S, Hikichi H, Fukushima M, Suzuki G, Kimura T, Tanaka T, Ito S, Kawamoto H, Ohta H. Pharmacological Effects of the Metabotropic Glutamate Receptor 1 Antagonist Compared with Those of the Metabotropic Glutamate Receptor 5 Antagonist and Metabotropic Glutamate Receptor 2/3 Agonist in Rodents: Detailed Investigations with a Selective Allosteric Metabotropic Glutamate Receptor 1 Antagonist, FTIDC [4-[1-(2-Fluoropyridine-3-yl)-5-methyl-1H-1,2,3-triazol-4-yl]-N-isopropyl-Nmethyl-3,6-dihydropyridine-1(2H)-carboxamide]. J Pharmacol Exp Ther. 2008; 326:577-86.

57. Satow A, Suzuki G, Maehara S, Hikichi H, Murai T, Murai T, Kawagoe-Takaki H, Hata M, Ito S, Ozaki S, et al. Unique Antipsychotic Activities of the Selective Metabotropic Glutamate Receptor 1 Allosteric Antagonist 2Cyclopropyl-5-[1-(2-fluoro-3-pyridinyl)-5-methyl-1H-1,2,3-triazol-4-yl]-2,3dihydro-1H-isoindol-1-one. J Pharmacol Exp Ther. 2009;330:179-90.

58. Ohta H, Kawamoto H, Suzuki G. mGluR1 Negative Allosteric Modulators: An Alternative Metabotropic Approach for the Treatment of Schizophrenia. Springer. 2010.

59. Conn PJ, Lindsley CW, Jones CK. Activation of metabotropic glutamate receptors as a novel approach for the treatment of schizophrenia. Trends Pharmacol Sci. 2009;30:25-31.

60. Jia Z, Janus C, Henderson JT, Gerlai R. Mice lacking metabotropic glutamate receptor 5 show impaired learning and reduced CA1 long-term potentiation (LTP) but normal CA3 LTP. J Neurosci. 1997;17:5196-205.

61. Manahan-Vaughan D, Braunewell K-H. The Metabotropic Glutamate Receptor, mGluR5, is a Key Determinant of Good and Bad Spatial Learning Performance and Hippocampal Synaptic Plasticity. Cereb Cortex. 2005;15: 1703-13.

62. Brody SA, Dulawa SC, Conquet F, Geyer MA. Assessment of a prepulse inhibition deficit in a mutant mouse lacking mGlu5 receptors. Mol Psychiatry. 2004;9(1):35-41.

63. Campbell UC, Lalwani K, Hernandez L, Kinney GG, Conn JP, Bristow LJ. The mGluR5 antagonist 2-methyl-6-(phenylethynyl)-pyridine (MPEP) potentiates PCP-induced cognitive deficits in rats. Psychopharmacology. 2004;175: 310-8.

64. Hu G, Duffy P, Swanson C, Ghasemzadeh MB, Kalivas PW. The Regulation of Dopamine Transmission by Metabotropic Glutamate Receptors. J Pharmacol Exp Ther. 1999;289:412-6.

65. Battaglia G, Fornai F, Busceti CL, Aloisi G, Cerrito F, De Blasi A, Melchiorri D, Nicoletti F. Selective Blockade of mGlu5 Metabotropic Glutamate Receptors Is Protective against Methamphetamine Neurotoxicity. J Neurosci. 2002;22: 2135-41.

66. Walker AG, Conn PJ. Group I and group II metabotropic glutamate receptor allosteric modulators as novel potential antipsychotics. Curr Opin Pharmacol. 2015;0:40-5

67. O'Brien JA, Lemaire W, Chen TB, Chang RS, Jacobson MA, Ha SN, Lindsley CW, Schaffhauser HJ, Sur C, Pettibone DJ, et al. A family of highly selective allosteric modulators of the metabotropic glutamate receptor subtype 5 . Mol Pharmacol. 2003:64:731-40.

68. O'Brien JA, Lemaire W, Wittmann M, Jacobson MA, Ha SN, Wisnoski DD, Lindsley CW, Schaffhauser HJ, Rowe B, Sur C, et al. A Novel Selective Allosteric Modulator Potentiates the Activity of Native Metabotropic Glutamate Receptor Subtype 5 in Rat Forebrain. J Pharmacol Exp Ther. 2004; 309:568-77. 
69. Lindsley CW, Wisnoski DD, Leister WH, O'Brien JA, Lemaire W, Williams DL, Burno M, Sur C, Kinney GG, Pettibone DJ, et al. Discovery of Positive Allosteric Modulators for the Metabotropic Glutamate Receptor Subtype 5 from a Series of N-(1,3-Diphenyl-1H- pyrazol-5-yl)benzamides That Potentiate Receptor Function in Vivo. J Med Chem. 2004;47:5825-8.

70. Kinney GG, O'Brien JA, Lemaire W, Burno M, Bickel DJ, Clements MK, Chen T-B, Wisnoski DD, Lindsley CW, Tiller PR, et al. A Novel Selective Positive Allosteric Modulator of Metabotropic Glutamate Receptor Subtype 5 Has in Vivo Activity and Antipsychotic-Like Effects in Rat Behavioral Models. J Pharmacol Exp Ther. 2005;313:199-206.

71. Kinney GG, Burno M, Campbell UC, Hernandez LM, Rodriguez D, Bristow LJ, Conn PJ. Metabotropic Glutamate Subtype 5 Receptors Modulate Locomotor Activity and Sensorimotor Gating in Rodents. J Pharmacol Exp Ther. 2003;306:116-23.

72. Ayala JE, Chen Y, Banko JL, Sheffler DJ, Williams R, Telk AN, Watson NL, Xiang Z, Zhang Y, Jones PJ, et al. mGluR5 Positive Allosteric Modulators Facilitate both Hippocampal LTP and LTD and Enhance Spatial Learning. Neuropsychopharmacology. 2009;34:2057-71.

73. Rodriguez AL, Grier MD, Jones CK, Herman EJ. Discovery of novel allosteric modulators of metabotropic glutamate receptor subtype 5 reveals chemical and functional diversity and in vivo activity in rat behavioral. Mol Pharmacol. 2010;78(6):1105-23.

74. Gastambide F, Cotel M-C, Gilmour G, O'Neill MJ, Robbins TW, Tricklebank MD. Selective Remediation of Reversal Learning Deficits in the Neurodevelopmental MAM Model of Schizophrenia by a Novel mGlu5 Positive Allosteric Modulator. Neuropsychopharmacology. 2011;37:1057-66.

75. Noetzel MJ, Rook JM, Vinson PN, Cho HP, Days E, Zhou Y, Rodriguez AL, Lavreysen H, Stauffer SR, Niswender CM. Functional impact of allosteric agonist activity of selective positive allosteric modulators of metabotropic glutamate receptor subtype 5 in regulating central nervous system function. Mol Pharmacol. 2012;81:120-33.

76. Parmentier-Batteur S, Hutson PH, Menzel K, Uslaner JM, Mattson BA, O'Brien JA, Magliaro BC, Forest T, Stump CA, Tynebor RM, et al. Mechanism based neurotoxicity of mGlu5 positive allosteric modulators - Development challenges for a promising novel antipsychotic target. Neuropharmacology. 2014;82:161-73.

77. Doherty AJ, Palmer MJ, Henley JM, Collingridge GL, Jane DE. (RS)-2-Chloro5-Hydroxyphenylglycine (CHPG) Activates mGlu5, but not mGlu1, Receptors Expressed in CHO Cells and Potentiates NMDA Responses in the Hippocampus. Neuropharmacology. 1997;36:265-7.

78. Doherty AJ, Palmer MJ, Bortolotto ZA, Hargreaves A, Kingston AE, Ornstein PL, Schoepp DD, Lodge D, Collingridge GL. A novel, competitive mGlu5 receptor antagonist (LY344545) blocks DHPG-induced potentiation of NMDA responses but not the induction of LTP in rat hippocampal slices. $\mathrm{Br}$ J Pharmacol. 2000;131:239-44.

79. Mannaioni G, Marino MJ, Valenti O. Metabotropic glutamate receptors 1 and 5 differentially regulate CA1 pyramidal cell function. J Neurosci. 2001; 21(16):5925-34.

80. Rook JM, Noetzel MJ, Pouliot WA, Bridges TM, Vinson PN, Cho HP, Zhou Y, Gogliotti RD, Manka JT, Gregory KJ, et al. Unique signaling profiles of positive allosteric modulators of metabotropic glutamate receptor subtype 5 determine differences in in vivo activity. Biol Psychiatry. 2013;73:501-9.

81. Rook JM, Xiang Z, LV X, Ghoshal A, Dickerson JW, Bridges TM, Johnson KA, Foster DJ, Gregory KJ, Vinson PN, et al. Biased mGlu5-Positive Allosteric Modulators Provide In Vivo Efficacy without Potentiating mGlu5 Modulation of NMDAR Currents. Neuron. 2015;86:1029-40.

82. Balu DT, Li Y, Takagi S, Presti KT, Ramikie TS, Rook JM, Jones CK, Lindsley CW, Conn PJ, Bolshakov VY, Coyle JT. An mGlu5-Positive Allosteric Modulator Rescues the Neuroplasticity Deficits in a Genetic Model of NMDA Receptor Hypofunction in Schizophrenia. Neuropsychopharmacology. 2016; 41(8):2052-61.

83. Balu DT, Coyle JT. Neuronal d-serine regulates dendritic architecture in the somatosensory cortex. Neurosci Lett. 2012;517:77-81.

84. Puhl MD, Berg AR, Bechtholt AJ, Coyle JT. Availability of N-Methyl-dAspartate Receptor Coagonists Affects Cocaine-Induced Conditioned Place Preference and Locomotor Sensitization: Implications for Comorbid Schizophrenia and Substance Abuse. J Pharmacol Exp Ther. 2015;353: 465-70.

85. Chevaleyre V, Castillo PE. Heterosynaptic LTD of Hippocampal GABAergic Synapses: A Novel Role of Endocannabinoids in Regulating Excitability. Neuron. 2003;38:461-72.
86. Fontanez-Nuin DE, Santini E, Quirk GJ, Porter JT. Memory for Fear Extinction Requires mGluR5-Mediated Activation of Infralimbic Neurons. Cereb Cortex. $2011 ; 21: 727-35$

87. Kiritoshi T, Sun H, Ren W, Stauffer SR, Lindsley CW, Conn PJ, Neugebauer V. Modulation of pyramidal cell output in the medial prefrontal cortex by mGluR5 interacting with CB1. Neuropharmacology. 2013;66:170-8.

88. Marek GJ, Zhang C. Activation of metabotropic glutamate 5 (mGlu5) receptors induces spontaneous excitatory synaptic currents in layer $\mathrm{V}$ pyramidal cells of the rat prefrontal cortex. Neurosci Lett. 2008;442:239-43.

89. Huber KM, Kayser MS, Bear MF. Role for Rapid Dendritic Protein Synthesis in Hippocampal mGluR-Dependent Long-Term Depression. Science. 2000;288: 1254-6.

90. Huber KM, Roder JC, Bear MF. Chemical Induction of mGluR5- and Protein Synthesis-Dependent Long-Term Depression in Hippocampal Area CA1. J Neurophysiol. 2001;86:321-5.

91. Gallagher SM, Daly CA, Bear MF, Huber KM. Extracellular Signal-Regulated Protein Kinase Activation Is Required for Metabotropic Glutamate ReceptorDependent Long-Term Depression in Hippocampal Area CA1. J Neurosci. 2004;24:4859-64.

92. Lynch MA. Long-Term Potentiation and Memory. Physiol Res. 2004;84: 87-136.

93. Rosenbrock H, Kramer G, Hobson S, Koros E, Grundl M, Grauert M, Reymann KG, Schröder UH. Functional interaction of metabotropic glutamate receptor 5 and NMDA-receptor by a metabotropic glutamate receptor 5 positive allosteric modulator. Eur J Pharmacol. 2010;639:40-6.

94. Balu DT, Li Y, Puhl MD, Benneyworth MA, Basu AC, Takagi S, Bolshakov VY, Coyle JT. Multiple risk pathways for schizophrenia converge in serine racemase knockout mice, a mouse model of NMDA receptor hypofunction. Proc Natl Acad Sci. 2013;110:E2400-9.

95. Benquet P, Gee CE, Gerber U. Two Distinct Signaling Pathways Upregulate NMDA Receptor Responses via Two Distinct Metabotropic Glutamate Receptor Subtypes. J Neurosci. 2002;22:9679-86.

96. Kotecha SA, Jackson MF, Al-Mahrouki A, Roder JC, Orser BA, MacDonald JF. Co-stimulation of mGluR5 and N-Methyl-D-aspartate Receptors Is Required for Potentiation of Excitatory Synaptic Transmission in Hippocampal Neurons. J Biol Chem. 2003;278:27742-9.

97. Collett VJ, Collingridge GL. Interactions between NMDA receptors and mGlu5 receptors expressed in HEK293 cells. Br J Pharmacol. 2004;142: $991-1001$.

98. Jin D-Z, Guo M-L, Xue B, Mao L-M, Wang JQ. Differential Regulation of CaMKIla Interactions with mGluR5 and NMDA Receptors by $\mathrm{Ca}(2+)$ in Neurons. J Neurochem. 2013;127:620-31.

99. Moutin E, Raynaud F, Roger J, Pellegrino E, Homburger V, Bertaso F, Ollendorff V, Bockaert J, Fagni L, Perroy J. Dynamic remodeling of scaffold interactions in dendritic spines controls synaptic excitability. J Cell Biol. 2012;198:251-63.

100. Hu J-H, Yang L, Kammermeier PJ, Moore CG, Brakeman PR, Tu J, Yu S, Petralia RS, Li Z, Zhang P-W, et al. Presol dynamically regulates group I metabotropic glutamate receptors. Nat Neurosci. 2012;15:836-44.

101. Park Joo M, Hu J-H, Milshteyn A, Zhang P-W, Moore Chester G, Park S, Datko Michael C, Domingo Racquel D, Reyes Cindy M, Wang Xiaodong J, et al. A Prolyl-Isomerase Mediates Dopamine-Dependent Plasticity and Cocaine Motor Sensitization. Cell. 2013;154:637-50.

102. Gao C, Tronson NC, Radulovic J. Modulation of behavior by scaffolding proteins of the post-synaptic density. Neurobiol Learn Mem. 2013;105:3-12.

103. Tanabe Y, Masu M, Ishii T, Shigemoto R, Nakanishi S. A family of metabotropic glutamate receptors. Neuron. 1992;8:169-79.

104. Nicoletti F, Bockaert J, Collingridge GL, Conn PJ, Ferraguti F, Schoepp DD, Wroblewski JT, Pin JP. Metabotropic glutamate receptors: From the workbench to the bedside. Neuropharmacology. 2011;60:1017-41.

105. Winder DG, Ritch PS, Gereau RW, Conn PJ. Novel glial-neuronal signalling by coactivation of metabotropic glutamate and beta-adrenergic receptors in rat hippocampus. J Physiol. 1996;494(Pt 3):743-55.

106. Winder DG, Conn PJ. Roles of metabotropic glutamate receptors in glial function and glial-neuronal communication. J Neurosci Res. 1996;46:131-7.

107. Johnson KA, Mateo Y, Lovinger DM. Metabotropic glutamate receptor 2 inhibits thalamically-driven glutamate and dopamine release in the dorsal striatum. Neuropharmacology. 2017;117:114-23.

108. Deakin JFW, Slater P, Simpson MDC, Gilchrist AC, Skan WJ, Royston MC, Reynolds GP, Cross AJ. Frontal Cortical and Left Temporal Glutamatergic Dysfunction in Schizophrenia. J Neurochem. 1989;52:1781-6. 
109. Liu J, Moghaddam B. Regulation of glutamate efflux by excitatory amino acid receptors: evidence for tonic inhibitory and phasic excitatory regulation. J Pharmacol Exp Ther. 1995;274:1209-15.

110. Homayoun H, Moghaddam B. NMDA Receptor Hypofunction Produces Opposite Effects on Prefrontal Cortex Interneurons and Pyramidal Neurons. J Neurosci. 2007:27:11496-500.

111. Moghaddam B, Adams B, Verma A, Daly D. Activation of Glutamatergic Neurotransmission by Ketamine: A Novel Step in the Pathway from NMDA Receptor Blockade to Dopaminergic and Cognitive Disruptions Associated with the Prefrontal Cortex. J Neurosci. 1997;17:2921-7.

112. Breier A, Malhotra AK, Pinals DA, Weisenfeld NI, Pickar D. Association of ketamine-induced psychosis with focal activation of the prefrontal cortex in healthy volunteers. Am J Psychiatry. 1997;154:805-11.

113. Vollenweider FX, Leenders KL, Øye I, Hell D, Angst J. Differential psychopathology and patterns of cerebral glucose utilisation produced by (S)- and (R)-ketamine in healthy volunteers using positron emission tomography (PET). Eur Neuropsychopharmacol. 1997;7:25-38.

114. Lorrain DS, Baccei CS, Bristow L, Anderson JJ, Varney MA. Effects of ketamine and $n$-methyl-d-aspartate on glutamate and dopamine release in the rat prefrontal cortex: modulation by a group II selective metabotropic glutamate receptor agonist LY379268. Neuroscience. 2003; 117:697-706

115. Schoepp DD, Jane DE, Monn JA. Pharmacological agents acting at subtypes of metabotropic glutamate receptors. Neuropharmacology. 1999;38: 1431-76.

116. Trepanier C, Lei G, Xie Y-F, MacDonald JF. Group II metabotropic glutamate receptors modify $\mathrm{N}$-methyl-D-aspartate receptors via Src kinase. Sci Rep. 2013:3:926.

117. Tyszkiewicz JP, Gu Z, Wang X, Cai X, Yan Z. Group II metabotropic glutamate receptors enhance NMDA receptor currents via a protein kinase C-dependent mechanism in pyramidal neurones of rat prefrontal cortex. J Physiol. 2004;554:765-77.

118. Cheng J, Liu W, Duffney LJ, Yan Z. SNARE proteins are essential in the potentiation of NMDA receptors by group II metabotropic glutamate receptors. J Physiol. 2013;591:3935-47.

119. González-Maeso J, Ang R, Yuen T, Chan P, Weisstaub NV, López-Giménez JF, Zhou M, Okawa Y, Callado LF, Milligan G, et al. Identification of a Novel Serotonin/Glutamate Receptor Complex Implicated in Psychosis. Nature. 2008:452:93-7.

120. Fribourg M, Moreno JL, Holloway T, Provasi D, Baki L, Mahajan R, Park G, Adney SK, Hatcher C, Eltit JM, et al. Decoding the Signaling of a GPCR Heteromeric Complex Reveals a Unifying Mechanism of Action of Antipsychotic Drugs. Cell. 2011;147:1011-23.

121. Moreno JL, Miranda-Azpiazu P, García-Bea A, Younkin J, Cui M, Kozlenkov A, Ben-Ezra A, Voloudakis G, Fakira AK, Baki L, et al. Allosteric signaling through an mGlu2 and 5-HT2A heteromeric receptor complex and its potential contribution to schizophrenia. Sci Signal. 2016:9:ra5.

122. Vollenweider FX, Vollenweider-Scherpenhuyzen MF, Babler A, Vogel H, Hell D. Psilocybin induces schizophrenia-like psychosis in humans via a serotonin-2 agonist action. Neuroreport. 1998;9:3897-902.

123. Aghajanian GK, Marek GJ. Serotonin Induces Excitatory Postsynaptic Potentials in Apical Dendrites of Neocortical Pyramidal Cells. Neuropharmacology. 1997:36:589-99.

124. Marek GJ, Wright RA, Gewirtz JC, Schoepp DD. A major role for thalamocortical afferents in serotonergic hallucinogen receptor function in the rat neocortex. Neuroscience. 2001;105:379-92.

125. Marek GJ, Wright RA, Schoepp DD, Monn JA, Aghajanian GK. Physiological Antagonism between 5-Hydroxytryptamine $<$ sub $>2 \mathrm{~A}</$ sub $>$ and Group II Metabotropic Glutamate Receptors in Prefrontal Cortex. J Pharmacol Exp Ther. 2000;292:76-87.

126. Kurita M, Holloway T, Garcia-Bea A, Kozlenkov A, Friedman AK, Moreno JL, Heshmati M, Golden SA, Kennedy PJ, Takahashi N, et al. HDAC2 regulates atypical antipsychotic responses through the modulation of $\mathrm{mGlu2}$ promoter activity. Nat Neurosci. 2012;15:1245-54

127. Moghaddam B, Adams BW. Reversal of Phencyclidine Effects by a Group II Metabotropic Glutamate Receptor Agonist in Rats. Science. 1998;281: 1349-52.

128. Homayoun $\mathrm{H}$, Jackson ME, Moghaddam B. Activation of Metabotropic Glutamate 2/3 Receptors Reverses the Effects of NMDA Receptor Hypofunction on Prefrontal Cortex Unit Activity in Awake Rats. Neurophysiol. 2005;93:1989-2001.
129. Rorick-Kehn LM, Johnson BG, Knitowski KM, Salhoff CR, Witkin JM, Perry KW, Griffey Kl, Tizzano JP, Monn JA, McKinzie DL, Schoepp DD. In vivo pharmacological characterization of the structurally novel, potent, selective mGlu2/3 receptor agonist LY404039 in animal models of psychiatric disorders. Psychopharmacology. 2007;193:121-36.

130. Lowe S, Dean R, Ackermann B, Jackson K, Natanegara F, Anderson S, Eckstein J, Yuen E, Ayan-Oshodi M, Ho M, et al. Effects of a novel mGlu2/3 receptor agonist prodrug, LY2140023 monohydrate, on central monoamine turnover as determined in human and rat cerebrospinal fluid. Psychopharmacology. 2012;219:959-70.

131. Mayada A, Pierri JN, Whitehead RE, Edgar CL, Carrie M, Sampson AR, Lewis DA. Lamina-Specific Alterations in the Dopamine Innervation of the Prefrontal Cortex in Schizophrenic Subjects. Am J Psychiatry. 1999;156:1580-9.

132. Goldman-Rakic PS, Muly IEC, Williams GV. D1 receptors in prefrontal cells and circuits. Brain Res Rev. 2000;31:295-301.

133. Pietro NCD, Seamans JK. Dopamine and Serotonin Interactions in the Prefrontal Cortex: Insights on Antipsychotic Drugs and Their Mechanism of Action. Pharmacopsychiatry. 2007;40:S27-33.

134. Sumiyoshi T, Kunugi H, Nakagome K. Serotonin and dopamine receptors in motivational and cognitive disturbances of schizophrenia. Front Neurosci. 2014:8:395.

135. Kinon BJ, Gómez J-C. Clinical development of pomaglumetad methionil: A non-dopaminergic treatment for schizophrenia. Neuropharmacology. 2013; 66:82-6.

136. Patil ST, Zhang L, Martenyi F, Lowe SL, Jackson KA, Andreev BV, Avedisova AS, Bardenstein LM, Gurovich IY, Morozova MA, et al. Activation of mGlu2/3 receptors as a new approach to treat schizophrenia: a randomized Phase 2 clinical trial. Nat Med. 2007:13:1102-7.

137. Kinon BJ, Zhang L, Millen BA, Osuntokun OO, Williams JE, Kollack-Walker S, Jackson K, Kryzhanovskaya L, Jarkova N, Group HS. A multicenter, inpatient, phase 2, double-blind, placebo-controlled dose-ranging study of LY2140023 monohydrate in patients with DSM-IV schizophrenia. J Clin Psychopharmacol. 2011;31:349-55.

138. Adams DH, Kinon BJ, Baygani S, Millen BA, Velona I, Kollack-Walker S, Walling DP. A long-term, phase 2, multicenter, randomized, open-label, comparative safety study of pomaglumetad methionil (LY2140023 monohydrate) versus atypical antipsychotic standard of care in patients with schizophrenia. BMC Psychiatry. 2013;13:143.

139. Downing AM, Kinon BJ, Millen BA, Zhang L, Liu L, Morozova MA, Brenner R, Rayle TJ, Nisenbaum L, Zhao F, Gomez JC. A double-blind, placebocontrolled comparator study of LY2140023 monohydrate in patients with schizophrenia. BMC Psychiatry. 2014;14:351.

140. Stauffer VL, Millen BA, Andersen S, Kinon BJ, LaGrandeur L, Lindenmayer JP, Gomez JC. Pomaglumetad methionil: No significant difference as an adjunctive treatment for patients with prominent negative symptoms of schizophrenia compared to placebo. Schizophr Res. 2013;150:434-41.

141. Galici R, Echemendia NG, Rodriguez AL, Conn PJ. A Selective Allosteric Potentiator of Metabotropic Glutamate (mGlu) 2 Receptors Has Effects Similar to an Orthosteric mGlu2/3 Receptor Agonist in Mouse Models Predictive of Antipsychotic Activity. J Pharmacol Exp Ther. 2005;315:1181-7.

142. Aultman MJ, Moghaddam B. Distinct contributions of glutamate and dopamine receptors to temporal aspects of rodent working memory using a clinically relevant task. Psychopharmacology. 2001;153:353-64.

143. Higgins GA, Ballard TM, Kew JNC, Grayson Richards J, Kemp JA, Adam G, Woltering T, Nakanishi S, Mutel V. Pharmacological manipulation of mGlu2 receptors influences cognitive performance in the rodent. Neuropharmacology. 2004;46:907-17.

144. Spooren WPJM, Gasparini F, van der Putten H, Koller M, Nakanishi S, Kuhn R. Lack of effect of LY314582 (a group 2 metabotropic glutamate receptor agonist) on phencyclidine-induced locomotor activity in metabotropic glutamate receptor 2 knockout mice. Eur J Pharmacol. 2000;397:R1-2.

145. Fell MJ, Svensson KA, Johnson BG, Schoepp DD. Evidence for the Role of Metabotropic Glutamate (mGlu)2 Not mGlu3 Receptors in the Preclinical Antipsychotic Pharmacology of the mGlu2/3 Receptor Agonist (-)-(1R,4S,5S,6S)-4-Amino-2-sulfonylbicyclo[3.1.0]hexane-4,6-dicarboxylic Acid (LY404039). J Pharmacol Exp Ther. 2008:326:209-17.

146. Johnson MP, Baez M, Jagdmann GE, Britton TC, Large TH, Callagaro DO, Tizzano JP, Monn JA, Schoepp DD. Discovery of Allosteric Potentiators for the Metabotropic Glutamate 2 Receptor: Synthesis and Subtype Selectivity of N-(4-(2-Methoxyphenoxy)phenyl)-N-(2,2,2- trifluoroethylsulfonyl)pyrid-3ylmethylamine. J Med Chem. 2003;46:3189-92. 
147. Schaffhauser $H$, Rowe BA, Morales $S$, Chavez-Noriega LE, Yin R, Jachec C, Rao SP, Bain G, Pinkerton AB, Vernier J-M, et al. Pharmacological Characterization and Identification of Amino Acids Involved in the Positive Modulation of Metabotropic Glutamate Receptor Subtype 2. Mol Pharmacol. 2003;64:798-810.

148. Bonnefous C, Vernier J-M, Hutchinson JH, Gardner MF, Cramer M, James JK, Rowe BA, Daggett LP, Schaffhauser H, Kamenecka TM. Biphenyl-indanones: Allosteric potentiators of the metabotropic glutamate subtype 2 receptor. Bioorg Med Chem Lett. 2005;15:4354-8.

149. Galici R, Jones CK, Hemstapat K, Nong Y, Echemendia NG, Williams LC, de Paulis T, Conn PJ. Biphenyl-indanone A, a Positive Allosteric Modulator of the Metabotropic Glutamate Receptor Subtype 2, Has Antipsychotic- and Anxiolytic-Like Effects in Mice. J Pharmacol Exp Ther. 2006;318:173-85.

150. Benneyworth MA, Xiang Z, Smith RL, Garcia EE, Conn PJ, Sanders-Bush E. A Selective Positive Allosteric Modulator of Metabotropic Glutamate Receptor Subtype 2 Blocks a Hallucinogenic Drug Model of Psychosis. Mol Pharmacol. 2007:72:477-84

151. Govek SP, Bonnefous C, Hutchinson JH, Kamenecka T, McQuiston J, Pracitto R, Zhao LX, Gardner MF, James JK, Daggett LP, et al. Benzazoles as allosteric potentiators of metabotropic glutamate receptor 2 (mGluR2): Efficacy in an animal model for schizophrenia. Bioorg Med Chem Lett. 2005;15:4068-72.

152. Johnson MP, Barda D, Britton TC, Emkey R, Hornback WJ, Jagdmann GE, McKinzie DL, Nisenbaum ES, Tizzano JP, Schoepp DD. Metabotropic glutamate 2 receptor potentiators: receptor modulation, frequencydependent synaptic activity, and efficacy in preclinical anxiety and psychosis model(s). Psychopharmacology. 2005;179:271-83.

153. Duplantier AJ, Efremov I, Candler J, Doran AC, Ganong AH, Haas JA, Hanks AN, Kraus KG, Lazzaro Jr JT, Lu J, et al. 3-Benzyl-1,3-oxazolidin-2-ones as mGluR2 positive allosteric modulators: Hit-to lead and lead optimization. Bioorg Med Chem Lett. 2009;19:2524-9.

154. Dhanya R-P, Sheffler DJ, Dahl R, Davis M, Lee PS, Yang L, Nickols HH, Cho HP, Smith LH, D'Souza MS, et al. Design and Synthesis of Systemically Active Metabotropic Glutamate Subtype-2 and -3 (mGlu2/3) Receptor Positive Allosteric Modulators (PAMs): Pharmacological Characterization and Assessment in a Rat Model of Cocaine Dependence. J Med Chem. 2014;57: 4154-72.

155. Hiyoshi T, Marumo T, Hikichi H, Tomishima Y, Urabe H, Tamita T, lida I, Yasuhara A, Karasawa J-I, Chaki S. Neurophysiologic and Antipsychotic Profiles of TASP0433864, a Novel Positive Allosteric Modulator of Metabotropic Glutamate 2 Receptor. J Pharmacol Exp Ther. 2014;351: 642-53.

156. Hikichi H, Hiyoshi T, Marumo T, Tomishima Y, Kaku A, lida I, Urabe H, Tamita T, Yasuhara A, Karasawa J-I, Chaki S. Antipsychotic profiles of TASP0443294, a novel and orally active positive allosteric modulator of metabotropic glutamate 2 receptor. J Pharmacol Sci. 2015;127:352-61.

157. Lavreysen H, Ahnaou A, Drinkenburg W, Langlois X, Mackie C, Pype S, Lütjens R, Le Poul E, Trabanco AA, Nuñez JMC. Pharmacological and pharmacokinetic properties of JNJ-40411813, a positive allosteric modulator of the mGlu2 receptor. Pharmacol Res Perspect. 2015;3:e00096.

158. Lavreysen $H$, Langlois $X$, Donck LV, Nuñez JMC, Pype S, Lütjens R, Megens A. Preclinical evaluation of the antipsychotic potential of the mGlu2-positive allosteric modulator JNJ-40411813. Pharmacol Res Perspect. 2015;3:e00097.

159. Litman RE, Smith MA, Doherty JJ, Cross A, Raines S, Gertsik L, Zukin SR. AZD8529, a positive allosteric modulator at the mGluR2 receptor, does not improve symptoms in schizophrenia: A proof of principle study. Schizophr Res. 2016;172:152-7.

160. Griebel G, Pichat P, Boulay D, Naimoli V, Potestio L, Featherstone R, Sahni S, Defex $H$, Desvignes $C$, Slowinski $F$, et al. The mGluR2 positive allosteric modulator, SAR218645, improves memory and attention deficits in translational models of cognitive symptoms associated with schizophrenia. Sci Rep. 2016;6:35320.

161. Salih H, Anghelescu I, Kezic I, Sinha V, Hoeben E, Van Nueten L, De Smedt $H$, De Boer P. Pharmacokinetic and pharmacodynamic characterisation of JNJ-40411813, a positive allosteric modulator of mGluR2, in two randomised, double-blind phase-I studies. J Psychopharmacol. 2015;29:414-25.

162. de la Fuente-Sandoval C, León-Ortiz P, Azcárraga M, Favila R, Stephano S, Graff-Guerrero A. Striatal glutamate and the conversion to psychosis: a prospective 1H-MRS imaging study. Int J Neuropsychopharmacol. 2013;16: 471-5.

163. de la Fuente-Sandoval C, León-Ortiz P, Azcárraga M, et al. Glutamate levels in the associative striatum before and after 4 weeks of antipsychotic treatment in first-episode psychosis: A longitudinal proton magnetic resonance spectroscopy study. JAMA Psychiatry. 2013;70:1057-66.

164. Egan MF, Straub RE, Goldberg TE, Yakub I, Callicott JH, Hariri AR, Mattay VS, Bertolino A, Hyde TM, Shannon-Weickert C, et al. Variation in GRM3 affects cognition, prefrontal glutamate, and risk for schizophrenia. Proc Natl Acad Sci U S A. 2004;101:12604-9.

165. Chen Q, He G, Chen Q, Wu S, Xu Y, Feng G, Li Y, Wang L, He L. A casecontrol study of the relationship between the metabotropic glutamate receptor 3 gene and schizophrenia in the Chinese population. Schizophr Res. 2005;73:21-6.

166. Harrison P, Lyon L, Sartorius L, Burnet $P$, Lane T. Review: The group II metabotropic glutamate receptor 3 (mGluR3, mGlu3, GRM3): expression, function and involvement in schizophrenia. J Psychopharmacol. 2008;22: 308-22.

167. Mössner R, Schuhmacher A, Schulze-Rauschenbach S, Kühn K-U, Rujescu D, Rietschel M, Zobel A, Franke P, Wölwer W, Gaebel W, et al. Further evidence for a functional role of the glutamate receptor gene GRM3 in schizophrenia. Eur Neuropsychopharmacol. 2008;18:768-72.

168. Joo A, Shibata H, Ninomiya H, Kawasaki H, Tashiro N, Fukumaki Y. Structure and polymorphisms of the human metabotropic glutamate receptor type 2 gene (GRM2): analysis of association with schizophrenia. Mol Psychiatry. 2001;6:186-92.

169. Tsunoka T, Kishi T, Kitajima T, Okochi T, Okumura T, Yamanouchi Y, Kinoshita Y, Kawashima K, Naitoh H, Inada T, et al. Association analysis of GRM2 and HTR2A with methamphetamine-induced psychosis and schizophrenia in the Japanese population. Prog Neuropsychopharmacol Biol Psychiatry. 2010;34: 639-44.

170. Schizophrenia Working Group of the Psychiatric Genomics C, Ripke S, Neale BM, Corvin A, Walters JTR, Farh K-H, Holmans PA, Lee P, Bulik-Sullivan B, Collier DA, et al. Biological Insights From 108 Schizophrenia-Associated Genetic Loci. Nature. 2014;511:421-7.

171. Dominguez C, Prieto L, Valli MJ, Massey SM, Bures M, Wright RA, Johnson BG, Andis SL, Kingston A, Schoepp DD, Monn JA. Methyl Substitution of 2Aminobicyclo[3.1.0]hexane 2,6-Dicarboxylate (LY354740) Determines Functional Activity at Metabotropic Glutamate Receptors: Identification of a Subtype Selective mGlu2 Receptor Agonist. J Med Chem. 2005;48:3605-12.

172. Li M-L, Yang S-S, Xing B, Ferguson BR, Gulchina Y, Li Y-C, Li F, Hu X-Q, Gao W-J. LY395756, an mGluR2 agonist and mGluR3 antagonist, enhances NMDA receptor expression and function in the normal adult rat prefrontal cortex, but fails to improve working memory and reverse MK801-induced working memory impairment. Exp Neurol. 2015;273:190-201.

173. Walker AG, Wenthur CJ, Xiang Z, Rook JM, Emmitte KA, Niswender CM, Lindsley CW, Conn PJ. Metabotropic glutamate receptor 3 activation is required for long-term depression in medial prefrontal cortex and fear extinction. Proc Natl Acad Sci. 2015;112:1196-201.

174. Bruno V, Sureda FX, Storto M, Casabona G, Caruso A, Knopfel T, Kuhn R, Nicoletti F. The Neuroprotective Activity of Group-II Metabotropic Glutamate Receptors Requires New Protein Synthesis and Involves a GlialNeuronal Signaling. J Neurosci. 1997;17:1891-7.

175. Bruno V, Battaglia G, Casabona G, Copani A, Caciagli F, Nicoletti F. Neuroprotection by Glial Metabotropic Glutamate Receptors Is Mediated by Transforming Growth Factor- $\beta$. J Neurosci Nurs. 1998;18:9594-600.

176. Durand D, Carniglia L, Caruso C, Lasaga M. mGlu3 receptor and astrocytes: Partners in neuroprotection. Neuropharmacology. 2013;66:1-11.

177. Bruno V, Caraci F, Copani A, Matrisciano F, Nicoletti F, Battaglia G. The impact of metabotropic glutamate receptors into active neurodegenerative processes: A "dark side" in the development of new symptomatic treatments for neurologic and psychiatric disorders. Neuropharmacology. 2016;115:180-92.

178. Monji A, Kato TA, Mizoguchi Y, Horikawa H, Seki Y, Kasai M, Yamauchi Y, Yamada S, Kanba S. Neuroinflammation in schizophrenia especially focused on the role of microglia. Prog Neuro-Psychopharmacol Biol Psychiatry. 2013; 42:115-21.

179. Najjar S, Pearlman DM. Neuroinflammation and white matter pathology in schizophrenia: systematic review. Schizophr Res. 2015;161:102-12.

180. Di Menna L, lacovelli L, Bruno V, Battaglia G, Nicoletti F. Functional cross-talk between group-I and group-II metabotropic glutamate receptors in heterologous expression systems and brain tissue. In Soc Neurosci Abs. 2015;2015:10.

181. Nakajima $Y$, Iwakabe $H$, Akazawa $C$, Nawa $H$, Shigemoto $R$, Mizuno $N$, Nakanishi S. Molecular characterization of a novel retinal metabotropic 
glutamate receptor mGluR6 with a high agonist selectivity for L-2-amino-4phosphonobutyrate. J Biol Chem. 1993;268:11868-73.

182. Saugstad JA, Kinzie JM, Mulvihill ER, Segerson TP, Westbrook GL. Cloning and expression of a new member of the L-2-amino-4-phosphonobutyric acid-sensitive class of metabotropic glutamate receptors. Mol Pharmacol. 1994:45:367-72.

183. Saugstad JA, Kinzie JM, Shinohara MM, Segerson TP, Westbrook GL. Cloning and expression of rat metabotropic glutamate receptor 8 reveals a distinct pharmacological profile. Mol Pharmacol. 1997;51:119-25.

184. Cartmell J, Schoepp DD. Regulation of Neurotransmitter Release by Metabotropic Glutamate Receptors. J Neurochem. 2000;75:889-907.

185. Shigemoto R, Kinoshita A, Wada E, Nomura S, Ohishi H, Takada M, Flor PJ, Neki A, Abe T, Nakanishi S, Mizuno N. Differential Presynaptic Localization of Metabotropic Glutamate Receptor Subtypes in the Rat Hippocampus. J Neurosci. 1997;17:7503-22

186. Corti C, Aldegheri L, Somogyi P, Ferraguti F. Distribution and synaptic localisation of the metabotropic glutamate receptor 4 (mGluR4) in the rodent CNS. Neuroscience. 2002;110:403-20.

187. Ohishi H, Akazawa C, Shigemoto R, Nakanishi S, Mizuno N. Distributions of the mRNAs for L-2-amino-4-phosphonobutyrate-sensitive metabotropic glutamate receptors, mGluR4 and mGluR7, in the rat brain. J Comp Neurol. 1995;360:555-70.

188. Pekhletski R, Gerlai R, Overstreet LS, Huang X-P, Agopyan N, Slater NT, Abramow-Newerly W, Roder JC, Hampson DR. Impaired Cerebellar Synaptic Plasticity and Motor Performance in Mice Lacking the mGluR4 Subtype of Metabotropic Glutamate Receptor. J Neurosci. 1996;16:6364-73.

189. Gerlai R, Roder JC, Hampson DR. Altered spatial learning and memory in mice lacking the mGluR4 subtype of metabotropic glutamate receptor. Behav Neurosci. 1998;112:525-32.

190. Pałucha-Poniewiera A, Kłodzińska A, Stachowicz K, Tokarski K, Hess G, Schann S, Frauli M, Neuville P, Pilc A. Peripheral administration of group III mGlu receptor agonist ACPT-I exerts potential antipsychotic effects in rodents. Neuropharmacology. 2008;55:517-24.

191. Wierońska JM, Stachowicz K, Acher F, Lech T, Pilc A. Opposing efficacy of group III mGlu receptor activators, LSP1-2111 and AMN082, in animal models of positive symptoms of schizophrenia. Psychopharmacology. 2012; 220:481-94.

192. Wozniak M, Acher F, Marciniak M, Lason-Tyburkiewicz M, Gruca P, Papp M, Pilc A, Wieronska JM. Involvement of GABAB Receptor Signaling in Antipsychotic-like Action of the Novel Orthosteric Agonist of the mGlu4 Receptor, LSP4-2022. Curr Neuropharmacol. 2016;14:413-26.

193. Bennouar K-E, Uberti MA, Melon C, Bacolod MD, Jimenez HN, Cajina M, Kerkerian-Le Goff L, Doller D, Gubellini P. Synergy between I-DOPA and a novel positive allosteric modulator of metabotropic glutamate receptor 4 : Implications for Parkinson's disease treatment and dyskinesia. Neuropharmacology. 2013;66:158-69.

194. East SP, Bamford S, Dietz MGA, Eickmeier C, Flegg A, Ferger B, Gemkow MJ, Heilker R, Hengerer B, Kotey A, et al. An orally bioavailable positive allosteric modulator of the mGlu4 receptor with efficacy in an animal model of motor dysfunction. Bioorg Med Chem Lett. 2010;20:4901-5.

195. Le Poul E, Boléa C, Girard F, Poli S, Charvin D, Campo B, Bortoli J, Bessif A, Luo B, Koser AJ, et al. A Potent and Selective Metabotropic Glutamate Receptor 4 Positive Allosteric Modulator Improves Movement in Rodent Models of Parkinson's Disease. J Pharmacol Exp Ther. 2012;343:167-77.

196. Sławińska A, Wierońska JM, Stachowicz K, Marciniak M, Łasoń-Tyburkiewicz M, Gruca P, Papp M, Kusek M, Tokarski K, Doller D, Pilc A. The antipsychoticlike effects of positive allosteric modulators of metabotropic glutamate mGlu4 receptors in rodents. Br J Pharmacol. 2013;169:1824-39.

197. Kalinichev M, Le Poul E, Boléa C, Girard F, Campo B, Fonsi M, Royer-Urios I, Browne SE, Uslaner JM, Davis MJ, et al. Characterization of the Novel Positive Allosteric Modulator of the Metabotropic Glutamate Receptor 4 ADX88178 in Rodent Models of Neuropsychiatric Disorders. J Pharmacol Exp Ther. 2014;350:495-505.

198. Romano C, Yang W-L, O'Malley KL. Metabotropic Glutamate Receptor 5 Is a Disulfide-linked Dimer. J Biol Chem. 1996;271:28612-6.

199. Doumazane E, Scholler P, Zwier JM, Trinquet E, Rondard P, Pin J-P. A new approach to analyze cell surface protein complexes reveals specific heterodimeric metabotropic glutamate receptors. FASEB J. 2011;25:66-77.

200. Kammermeier PJ. Functional and pharmacological characteristics of metabotropic glutamate receptors 2/4 heterodimers. Mol Pharmacol. 2012; 82:438-47.
201. Yin S, Noetzel MJ, Johnson KA, Zamorano R, Jalan-Sakrikar N, Gregory K, Conn PJ, Niswender CM. Selective Actions of Novel Allosteric Modulators Reveal Functional Heteromers of Metabotropic Glutamate Receptors in the CNS. J Neurosc. 2013;34:79-94.

202. Niswender CM, Jones CK, Lin X, Bubser M, Thompson Gray A, Blobaum AL, Engers DW, Rodriguez AL, Loch MT, Daniels JS, et al. Development and Antiparkinsonian Activity of VU0418506, a Selective Positive Allosteric Modulator of Metabotropic Glutamate Receptor 4 Homomers without Activity at mGlu2/4 Heteromers. ACS Chem Nerosci. 2016;7: 1201-11.

203. Ohtsuki T, Koga M, Ishiguro H, Horiuchi Y, Arai M, Niizato K, Itokawa M, Inada T, Iwata N, Iritani S, et al. A polymorphism of the metabotropic glutamate receptor mGluR7 (GRM7) gene is associated with schizophrenia. Schizophr Res. 2008;101:9-16.

204. Kinzie JM, Saugstad JA, Westbrook GL, Segerson TP. Distribution of metabotropic glutamate receptor 7 messenger RNA in the developing and adult rat brain. Neuroscience. 1995;69:167-76.

205. Mercier MS, Lodge D. Group III Metabotropic Glutamate Receptors: Pharmacology, Physiology and Therapeutic Potential. Neurochem Res. 2014; 39:1876-94.

206. Masugi M, Yokoi M, Shigemoto R, Muguruma K, Watanabe Y, Sansig G, van der Putten H, Nakanishi S. Metabotropic glutamate receptor subtype 7 ablation causes deficit in fear response and conditioned taste aversion. J Neurosci. 1999:19:955-63.

207. Holscher C, Schmid S, Pilz PK, Sansig G, van der Putten H, Plappert CF. Lack of the metabotropic glutamate receptor subtype 7 selectively impairs shortterm working memory but not long-term memory. Behav Brain Res. 2004; 154:473-81.

208. Goddyn H, Callaerts-Vegh Z, Stroobants S, Dirikx T, Vansteenwegen D, Hermans D, van der Putten H, D'Hooge R. Deficits in acquisition and extinction of conditioned responses in mGluR7 knockout mice. Neurobiol Learn Mem. 2008;90:103-11.

209. Callaerts-Vegh Z, Beckers T, Ball SM, Baeyens F, Callaerts PF, Cryan JF, Molnar E, D'Hooge R. Concomitant deficits in working memory and fear extinction are functionally dissociated from reduced anxiety in metabotropic glutamate receptor 7-deficient mice. J Neurosci. 2006;26:6573-82.

210. Baskys A, Malenka RC. Agonists at metabotropic glutamate receptors presynaptically inhibit EPSCs in neonatal rat hippocampus. J Physiol. 1991; 444:687-701.

211. Ayala JE, Niswender CM, Luo Q, Banko JL, Conn PJ. Group III mGluR regulation of synaptic transmission at the SC-CA1 synapse is developmentally regulated. Neuropharmacology. 2008;54:804-14.

212. Klar R, Walker AG, Ghose D, Grueter BA, Engers DW, Hopkins CR, Lindsley CW, Xiang Z, Conn PJ, Niswender CM. Activation of Metabotropic Glutamate Receptor 7 Is Required for Induction of Long-Term Potentiation at SC-CA1 Synapses in the Hippocampus. J Neurosci. 2015;35:7600-15.

213. Tassin V, Girard B, Chotte A, Fontanaud P, Rigault D, Kalinichev M, Perroy J, Acher F, Fagni L, Bertaso F. Phasic and Tonic mGlu7 Receptor Activity Modulates the Thalamocortical Network. Front Neural Circuits. 2016;10:31.

214. Klingner CM, Langbein K, Dietzek M, Smesny S, Witte OW, Sauer H, Nenadic I. Thalamocortical connectivity during resting state in schizophrenia. Eur Arch Psychiatry Clin Neurosci. 2014;264:111-9.

215. Mitsukawa K, Yamamoto R, Ofner S, Nozulak J, Pescott O, Lukic S, Stoehr N, Mombereau C, Kuhn R, McAllister KH, et al. A selective metabotropic glutamate receptor 7 agonist: Activation of receptor signaling via an allosteric site modulates stress parameters in vivo. Proc Natl Acad Sci U S A. 2005;102:18712-7.

216. Sukoff Rizzo SJ, Leonard SK, Gilbert A, Dollings P, Smith DL, Zhang M-Y, Di L, Platt BJ, Neal S, Dwyer JM, et al. The Metabotropic Glutamate Receptor 7 Allosteric Modulator AMN082: A Monoaminergic Agent in Disguise? J Pharmacol Exp Ther. 2011;338:345-52.

217. Kinoshita A, Ohishi H, Neki A, Nomura S, Shigemoto R, Takada M, Nakanishi S, Mizuno N. Presynaptic localization of a metabotropic glutamate receptor, mGluR8, in the rhinencephalic areas: a light and electron microscope study in the rat. Neurosci Lett. 1996;207:61-4.

218. Zhai J, Tian MT, Wang Y, Yu JL, Koster A, Baez M, Nisenbaum ES. Modulation of lateral perforant path excitatory responses by metabotropic glutamate 8 (mGlu8) receptors. Neuropharmacology. 2002:43:223-30.

219. Gerlai R, Adams B, Fitch T, Chaney S, Baez M. Performance deficits of mGluR8 knockout mice in learning tasks: the effects of null mutation and the background genotype. Neuropharmacology. 2002;43:235-49. 
220. Gosnell HB, Silberman Y, Grueter BA, Duvoisin RM, Raber J, Winder DG. mGluR8 Modulates Excitatory Transmission in the Bed Nucleus of the Stria Terminalis in a Stress-Dependent Manner. Neuropsychopharmacology. 2011; 36:1599-607.

221. Robbins MJ, Starr KR, Honey A, Soffin EM, Rourke C, Jones GA, Kelly FM, Strum J, Melarange RA, Harris AJ, et al. Evaluation of the mGlu8 receptor as a putative therapeutic target in schizophrenia. Brain Res. 2007;1152:215-27.

222. Thomas NK, Wright RA, Howson PA, Kingston AE, Schoepp DD, Jane DE. (S)3,4-DCPG, a potent and selective $m G$ lu8a receptor agonist, activates metabotropic glutamate receptors on primary afferent terminals in the neonatal rat spinal cord. Neuropharmacology. 2001;40:311-8.

223. Vardigan JD, Huszar SL, McNaughton CH. MK-801 produces a deficit in sucrose preference that is reversed by clozapine, D-serine, and the metabotropic glutamate 5 receptor positive allosteric modulator CDPPB: relevance to negative symptoms associated with schizophrenia? Pharmacol Biochem Behav. 2010;95(2):223-9.

224. Stefani MR, Moghaddam B. Activation of type 5 metabotropic glutamate receptors attenuates deficits in cognitive flexibility induced by NMDA receptor blockade. Eur J Pharmacol. 2010;639:26-32.

225. Horio M, Fujita Y, Hashimoto K. Therapeutic effects of metabotropic glutamate receptor 5 positive allosteric modulator CDPPB on phencyclidineinduced cognitive deficits in mice. Fundam Clin Pharmacol. 2013;27:483-8.

226. Cartmell J, Monn JA, Schoepp DD. The Metabotropic Glutamate 2/3 Receptor Agonists LY354740 and LY379268 Selectively Attenuate Phencyclidine versus d-Amphetamine Motor Behaviors in Rats. J Pharmacol Exp Ther. 1999:291:161-70.

227. Schlumberger C, Pietraszek M, Gravius A, Klein K-U, Greco S, Morè L, Danysz W. Comparison of the $\mathrm{mGlu} 5$ receptor positive allosteric modulator ADX47273 and the mGlu2/3 receptor agonist LY354740 in tests for antipsychotic-like activity. Eur J Pharmacol. 2009;623:73-83.

228. Kłodzinska A, Bijak M, Tokarski K, Pilc A. Group II mGlu receptor agonists inhibit behavioural and electrophysiological effects of DOI in mice. Pharmacol Biochem Behav. 2002;73:327-32.

229. Harich S, Gross G, Bespalov A. Stimulation of the metabotropic glutamate 2/ 3 receptor attenuates social novelty discrimination deficits induced by neonatal phencyclidine treatment. Psychopharmacology. 2007;192:511-9.

230. Kawaura K, Karasawa J-I, Hikichi H. Stimulation of the metabotropic glutamate ( $\mathrm{mGlu}$ ) 2 receptor attenuates the MK-801-induced increase in the immobility time in the forced swimming test in rats. Pharmacol Rep. 2016; 68:80-4.

231. Matrisciano F, Tueting P, Maccari S, Nicoletti F, Guidotti A. Pharmacological Activation of Group-II Metabotropic Glutamate Receptors Corrects a Schizophrenia-Like Phenotype Induced by Prenatal Stress in Mice. Neuropsychopharmacology. 2012;37:929-38.

232. Jones CA, Brown AM, Auer DP, Fone KCF. The mGluR2/3 agonist LY379268 reverses post-weaning social isolation-induced recognition memory deficits in the rat. Psychopharmacology. 2011;214:269-83.

233. Hikichi H, Kaku A, Karasawa J-I, Chaki S. Stimulation of Metabotropic Glutamate (mGlu) 2 Receptor and Blockade of mGlu1 Receptor Improve Social Memory Impairment Elicited by MK-801 in Rats. J Pharmacol Sci. 2013;122:10-6.

234. Wierońska JM, Sławińska A, Stachowicz K, Łasoń-Tyburkiewicz M, Gruca P, Papp M, Pilc A. The reversal of cognitive, but not negative or positive symptoms of schizophrenia, by the mGlu2/3 receptor agonist, LY379268, is 5-HT1A dependent. Behav Brain Res. 2013;256:298-304.

235. Greco B, Invernizzi RW, Carli M. Phencyclidine-induced impairment in attention and response control depends on the background genotype of mice: reversal by the mGLU2/3 receptor agonist LY379268. Psychopharmacology. 2005;179:68-76.

236. Amitai N, Markou A. Effects of metabotropic glutamate receptor $2 / 3$ agonism and antagonism on schizophrenia-like cognitive deficits induced by phencyclidine in rats. Eur J Pharmacol. 2010;639:67-80

237. Nikiforuk A, Popik P, Drescher KU, van Gaalen M, Relo A-L, Mezler M, Marek G, Schoemaker H, Gross G, Bespalov A. Effects of a Positive Allosteric Modulator of Group II Metabotropic Glutamate Receptors, LY487379, on Cognitive Flexibility and Impulsive-Like Responding in Rats. J Pharmacol Exp Ther. 2010;335:665-73.

238. Wierońska JM, Zorn SH, Doller D, Pilc A. Metabotropic glutamate receptors as targets for new antipsychotic drugs: Historical perspective and critical comparative assessment. Pharmacol Ther. 2016;157:10-27.

\section{Submit your next manuscript to BioMed Central and we will help you at every step:}

- We accept pre-submission inquiries

- Our selector tool helps you to find the most relevant journal

- We provide round the clock customer support

- Convenient online submission

- Thorough peer review

- Inclusion in PubMed and all major indexing services

- Maximum visibility for your research

Submit your manuscript at www.biomedcentral.com/submit
Biomed Central 